\title{
Burnout and work engagement for different age groups: Examining group-level differences and predictors
}

\author{
Lize-Mari Haley, Hons BCom
}

This mini-dissertation is submitted in partial fulfilment for the requirements of the degree Magister Commercii Industrial Psychology at the

North-West University (Potchefstroom Campus)

Supervisor: Prof. K. Mostert

Assistant supervisor: Mrs. C. Els

September 2012

Potchefstroom 


\section{COMMENTS}

The reader is reminded of the following:

- The editorial style as well as the references referred to in this mini-dissertation follow the format prescribed by the Publication Manual $\left(6^{\text {th }}\right.$ edition) of the American Psychological Association (APA). This practice is in line with the policy of the Programme in Industrial Psychology of the North-West University (Potchefstroom) to use APA style in all scientific documents as from January 1999.

- The mini-dissertation is submitted in the form of a research article. The editorial style specified by the South African Journal of Industrial Psychology (which agrees largely with the APA style) is used, but the APA guidelines were followed in referencing and constructing tables. 


\section{ACKNOWLEDGEMENTS}

My gratitude goes out to everyone who played a part in the completion of my Masters degree and I thank you. Specifically I would like to thank the following:

- My Heavenly Father for blessing me with this opportunity as well as the talent to study and ultimately finishing my Masters.

- Philip Vorster, thank you for always being there for me, for loving me regardless and for being my rock when I wanted to fall to all the pressure. I am really blessed to have had someone like you throughout my university career, always willing to help where you can. I am sure you are just as competent now in this field! Words cannot describe my love for you and I am looking forward to the next chapter of our lives together as Industrial Scientist and Industrial Psychologist.

- My parents, Annelie de Villiers and Peter Haley. Mom, thank you for always listening when I needed you and for your never ending love and support for my studies and life in general and Dad, thank you for all the love and encouragement in the final days of this dissertation when I needed it the most and for always helping where you can.

- My brother, Captain Denis Haley - your wisdom regarding our field will always astonish me. Thank you for always being there when I needed you and for all your love and support during challenging and less challenging times.

- Prof. Karina Mostert and Mrs. Crizelle Els, my supervisor and assistant supervisor. Prof. Karina, thank you for your expertise, help and guidance through this whole journey to make the end product the best it can be and Crizelle thank you for always making me see the bigger picture when I was caught in the minor details of this dissertation and guiding me on to the right track again. I feel proud to have studied under both of you.

- Lizelle Brink, thank you for keeping me motivated every time I felt I was not keeping up and always making time for me. I will cherish our coffee and 'fun times' for life. You are a mentor and friend to me forever.

- Lastly, I want to thank the rest of my family and friends. Even though you are not mentioned by name, all of you played a part in this chapter of my life, shaping who I am today and I thank you for that. 


\section{TABLE OF CONTENTS}

List of Tables

Abstract

Opsomming

\section{CHAPTER 1: INTRODUCTION}

1.1 Problem statement

1.2 Research objectives

1.2.1 General objective

1.2.2 Specific objectives

1.3 Research design

1.3.1 Research approach

1.3.2 Research method

1.3.3 Literature review

1.3.4 Research participants 9

$\begin{array}{ll}\text { 1.3.5 Measuring instruments } & 10\end{array}$

$\begin{array}{lll}\text { 1.3.6 Research procedure } & 11\end{array}$

1.3.7 Statistical analysis $\quad 11$

1.4 Overview of chapters 12

$\begin{array}{lll}1.5 & \text { Chapter summary } & 12\end{array}$

$\begin{array}{ll}\text { References } & 13\end{array}$

CHAPTER 2: RESEARCH ARTICLE 18

$\begin{array}{ll}\text { Abstract } & 19\end{array}$

$\begin{array}{ll}\text { Introduction } & 20\end{array}$

$\begin{array}{ll}\text { Literature review } & 22\end{array}$

$\begin{array}{ll}\text { Burnout and work engagement } & 22\end{array}$

$\begin{array}{ll}\text { Age, burnout and work engagement } & 23\end{array}$

The Job Demands-Resources model and personal resources 24

$\begin{array}{ll}\text { Research design } & 27\end{array}$

$\begin{array}{ll}\text { Research approach } & 27\end{array}$

$\begin{array}{ll}\text { Research method } & 27\end{array}$ 


\section{TABLE OF CONTENTS CONTINUED}

$\begin{array}{ll}\text { Research participants } & 27\end{array}$

$\begin{array}{ll}\text { Measuring instruments } & 29\end{array}$

$\begin{array}{ll}\text { Research procedure } & 30\end{array}$

$\begin{array}{ll}\text { Statistical analysis } & 30\end{array}$

Results 31

$\begin{array}{lr}\text { Discussion } & 50\end{array}$

Limitations $\quad 54$

Recommendations $\quad 55$

$\begin{array}{ll}\text { References } & 57\end{array}$

CHAPTER 3: CONCLUSIONS, LIMITATIONS AND RECOMMENDATIONS

3.1 Conclusions $\quad 62$

3.2 Limitations 66

3.3 Recommendations 66

3.3.1 Recommendations for the organisation 66

3.3.2 Recommendations for the individual 67

$\begin{array}{lll}\text { 3.3.3 Recommendations for future research } & 67\end{array}$

$\begin{array}{ll}\text { References } & 69\end{array}$ 


\section{LIST OF TABLES}

Table $1 \quad$ Characteristics of participants $(n=582)$

Table 2 Descriptive statistics, Cronbach alpha coefficients of the measuring instruments and correlation coefficients

Table 3 ANOVA - Differences in burnout based on age

Table 4 Hierarchical multiple regression analysis with exhaustion as dependent variable

Table 5 Hierarchical multiple regression analysis with cynicism as dependent variable

Table 6 Hierarchical multiple regression analysis with vigour as dependent variable

Table 7 Hierarchical multiple regression analysis with dedication as dependent variable

Table 8 Summary of significant predictors of well-being across the three age groups 


\begin{abstract}
Title: Burnout and work engagement for different age groups: Examining group-level differences and predictors

Keywords: Job demands, job resources, burnout, work engagement, Job Demands-Resources (JD-R) Model, sense of coherence (SOC), age

Age is often a factor which can have an effect on the well-being levels of employees as well as the profitability of organisations, but it is unfortunately at times overlooked by organisations. Many researchers have found that employees can differ in their experiences of well-being (burnout and work engagement) as a result of age and that there may be differences in the job demands, job resources and personal resources, which predict wellbeing.
\end{abstract}

The objectives of this study were to determine 1) whether there are significant differences between young, middle-aged and older employees with regards to their experiences of burnout and work engagement, and 2) whether the predictors (job demands and job resources, sense of coherence) of burnout and work engagement differ for young, middle age and older employees. The South African Employee Health and Wellness survey (SAEHWS), a selfreport measure, was used to collect data from the junior managers $(n=582)$ in the banking sector across South Africa. The participants were subsequently divided into three age groups, namely young (18-30 years of age), middle-aged (31-50 years of age) and older employees (51-65 years of age). MANOVA was used to determine if there were any significant differences between well-being and age after which an ANOVA was performed. The results of the ANOVA analysis firstly showed that young and middle-aged employees experienced higher levels of exhaustion than their older colleagues did. Cynicism however, did not differ across the three groups. Even though there did not seem to be overall significant differences between age and work engagement, the post hoc analysis revealed that older employees seemed to experience significantly higher levels of dedication compared to younger employees. There were no differences between the age groups found for vigour. Hierarchical multiple regression analysis indicated that different job demands and resources predict wellbeing for the different age group with the exception of emotional load, which predicted exhaustion for all three age groups. However, SOC was consistently significant across all 
three age groups with regards to predicting their well-being. SOC seemed to increase with age as experience is obtained.

These findings contribute to the literature by highlighting the importance of age when considering interventions to keep their employees from burnout and disengagement, especially for South African organisations. Age definitely seems to play a role in the experiences of well-being according to the findings and also aid in the explanation of what different job characteristics employees seemed to value across their ages. Older employees also seemed to use their personal resources more efficiently as they get older in order to build positive well-being.

The results of this study can assist organisations in the financial sector to create sufficient interventions for ensuring high levels of well-being, as the findings highlight specific job demands and resources that can assist in that goal. Moreover, there is limited research on the topic within a South African context, therefore the results of this research also serves to encourage South African organisations to act proactively in the promotion of positive wellbeing.

Recommendations were made for practice as well as for future research. 


\section{OPSOMMING}

Titel: Uitbranding en werksbegeestering vir verskillende ouderdoms groepe: Bestudering van groep-vlak verskille en voorspellers

Sleutelterme: Werkseise, werkhulpbronne, uitbranding, werksbegeestering, WerkseiseHulpbronne model, sin vir koherensie, ouderdom

Ouderdom is dikwels 'n faktor wat 'n effek kan hê op die welstand van werknemers, sowel as organisasies se winsgewendheid, maar word dikwels deur organisasies oorgesien. Baie navorsers het bevind dat werknemers kan verskil in hul ervarings van welstand (uitbranding en werksbegeestering) as gevolg van ouderdom en dat daar moontlik verskille in die werkseise, werk hulpbronne en persoonlike hulpbronne kan wees wat welstand voorspel.

Die doelwitte van hierdie studie was om vas te stel 1) of daar beduidende verskille tussen jong, middeljarige ouderdom en ouer werknemers is met betrekking tot hulle ervarings van uitbranding en werksbegeestering en 2) of die voorspellers (werkseise en werkhulpbronne, sin vir koherensie) van uitbranding en werksbegeestering verskil vir jong, middeljarige ouderdom en ouer werknemers. Die 'South African Employee Health and Wellness survey' (SAEHWS), 'n self-invul vraelys, is gebruik om data van junior bestuurders $(n=582)$ in die banksektor oor Suid-Afrika in te samel. Die deelnemers is verdeel in drie ouderdomsgroepe, naamlik jong (18-30 jaar oud), middeljarige (31-50 jaar oud) en ouer bestuurders (51-65 jaar oud). MANOVA is gebruik om te bepaal of daar enige beduidende verskille tussen welstand en ouderdom was, waarna 'n ANOVA uitgevoer is. Die resultate van die ANOVA-analise het eerstens getoon dat jong en middeljarige bestuurders hoër vlakke van uitputting ervaar in vergelyking met hul ouer kollegas. Sinisme het egter nie oor die drie groepe verskil nie. Selfs al was daar nie algehele beduidende verskille tussen ouderdom en werksbegeestering nie, het die post hoc-analise getoon dat ouer werknemers aansienlik hoër vlakke van toewyding ervaar in vergelyking met jonger werknemers. Daar was geen verskille gevind ten opsigte van energie nie. Hiërargiese meervoudige regressie-analise het getoon dat verskillende werkseise en hulpbronne welstand voorspel het vir die verskillende ouderdoms groepe met die uitsondering van emosionele las, wat vir al drie ouderdoms groepe uitputting voorspel het. Sin vir koherensie was deurgaans betekenisvol oor al drie ouderdoms groepe in die voorspelling 
van welstand. Sin vir koherensie blyk om te verhoog met ouderdom soos wat ervaring opgedoen word.

Die bevindinge lewer ' $n$ bydrae tot die literatuur deur die belangrikheid van ouderdom uit te lig wanneer intervensies ontwikkel moet word om hul werknemers weg te hou van uitbranding en ontkoppeling, veral vir die Suid-Afrikaanse organisasies. Ouderdom blyk volgens die bevindinge om beslis ' $\mathrm{n}$ rol te speel in die ervaring van welstand en help ook met die verduideliking van watter verskillende werkeienskappe werknemers van verskillende ouderdomme as belangrik ag. Dit wil voorkom of ouer werknemers hul persoonlike hulpbronne meer doeltreffend gebruik namate hulle ouer word in die opbouing van positiewe welstand.

Die resultate van hierdie studie kan organisasies in die finansiële sektor help om voldoende intervensies te ontwikkel om ten einde te verseker dat daar hoë vlakke van welstand is juis omdat die bevindinge spesifieke werkseise en hulpbronne aantoon wat in die lig van hierdie doel waarde kan toevoeg. Verder is daar min navorsing oor die onderwerp binne 'n SuidAfrikaanse konteks beskikbaar, dus benadruk hierdie navorsing ook dat Suid-Afrikaanse organisasies pro-aktief moet optree in die bevordering van positiewe welstand.

Aanbevelings word ten slotte gemaak vir die praktyk sowel as vir toekomstige navorsing. 


\section{CHAPTER 1}

\section{INTRODUCTION}

This mini dissertation explores how age can play a role in how young, middle aged and older workers experience burnout and work engagement within the South African banking industry. It also examines if there are differences in the predictors of burnout and work engagement across the three age groups. The predictors include job demands, job resources, and sense of coherence as a personal resource.

In this chapter, the problem statement is discussed as well as the research objectives in terms of the general and specific objectives. This chapter also includes the research design as well as an overview of the chapters.

\subsection{PROBLEM STATEMENT}

Over the past few years, attention has shifted from the traditional view of psychology, mainly focusing on ailments and disorders, for example, to a more positive outlook concentrating more on the strengths of the employees and their optimal functioning when looking at wellbeing (Schaufeli, Bakker \& Salanova, 2006). This is also referred to as positive psychology (Seligman \& Csikszentmihalyi, 2000). Well-being can play a significant role in organisational performance. Having employees with high levels of well-being can lead to an increase in their commitment within the organisation, which can ultimately exert an impact on the bottom line of the company (Macey \& Schneider, 2008).

Two concepts related to well-being widely researched across literature are burnout and work engagement (Bakker, Albrecht \& Leiter, 2011; Schaufeli, Leiter \& Maslach, 2009). In recent years both burnout and engagement research have received a great deal of attention from researchers and the general public alike (Bakker, Hakanen, Demerouti \& Xanthopoulou, 2007; De Lange, De Witte \& Notalaers, 2008; Dikkers, Jansen, De Lange, Vinkenburg \& Kooij, 2010; Schaufeli et al., 2009). Research with regards to burnout primarily focuses on the identification of early signs thereof and to better understand the course of action to be taken when burnout does occur in the workplace (Maslach \& Leiter, 2008). With regards to work engagement, Bakker and Bal (2010) state that engagement is beneficial for 
organisations as it is positively related to, for example, performance, client satisfaction, and their employee's business unit's performance.

Maslach, Leiter and Schaufeli (2008) define burnout as "a psychological syndrome in response to chronic interpersonal stressors on the job" (p. 90). Burnout, therefore, is a work related stress reaction within the employee, which develops as a reaction to stress when a gap exists between the employee having a strong motivation towards their job and an adverse work setting (Bakker, Van Emmerik \& Euwema, 2006; Gustavsson, Hallsten \& Rudman, 2010). Burnout consists of three dimensions, namely exhaustion, cynicism, and reduced personal efficacy (Maslach, Schaufeli \& Leiter, 2001). Exhaustion is characterised by feelings of strain, and more specifically chronic fatigue as a result of overworking. Exhaustion thus leads to employees being drained of all their energy, which leads to them being incapable of performing at their best. Cynicism is characterised by losing interest in ones work and distancing oneself from ones work as it no longer seems to have any meaning (Maslach et al., 2001). Lastly, reduced personal efficacy is characterised by a reduced feeling of being successful and reduced feelings of achievement within the job as well as in the organisation (Maslach et al., 2001). Exhaustion and cynicism are viewed as the core concepts of burnout whereas personal efficacy reflects more of a characteristic of one's personality (Cordes \& Dougherty, 1993). Personal efficacy also appears to develop parallel and not sequentially to the two core concepts (Leiter, 1993).

Previous studies have indicated that burnout is correlated with many negative aspects of the job such as job dissatisfaction, low organisational commitment, absenteeism, intention to leave the organisation and organisational turnover (Maslach \& Leiter, 2008). Burnt out individuals can suffer from fatigue, their behaviour may change towards their organisation and their clients, and these employees seem to believe that their performance has suffered because they are burnt out (Bakker et al., 2006). Therefore, the consequences of burnout can be labelled as being potentially very serious and could result in negative consequences for both the organisation and the individual (Angerer, 2003; Rothmann, 2003).

However, on the more positive side, work engagement can be very beneficial for the organisation. Schaufeli, Salanova, González-Romá and Bakker (2002) define work engagement as "a positive, fulfilling, work-related state of mind that is characterised by vigour, dedication, and absorption" (p. 74). Vigour is experienced when an employee has 
high levels of energy and mental resilience while performing their job, as well as eagerness to put effort into their work regardless of any obstacles. Dedication is described as having a sense of "significance, enthusiasm, inspiration, pride and challenge" within their work environment (Schaufeli et al., 2002, p. 74). Finally, absorption is characterised by an employee being immersed in their work to such an extent that they are not easily detached from their work (Schaufeli et al., 2002). Similar to burnout, vigour and dedication are considered as the two core concepts of engagement while absorption is a characteristic that is "not the end point of some underlying continuum" (Schaufeli et al., 2002, p. 74). Having engaged employees in an organisation can result in an energetic workforce that enjoys a more effective connection with their jobs and thus deals more efficiently with the demands encountered (Schaufeli et al., 2002). According to Gruman and Saks (2011), work engagement has been referred to as the concept that is often the key to a company's success as well as its competitive advantage. McBain (2006) states that if employees are indeed engaged it can increase the performance of the individual employees and teams within the organisation, and thus this would positively impact the organisation's performance as a whole.

Studies have indicated that if organisations ensure the engagement of their employees this would lead to a more positive working environment for all. For example, Salanova, Agut and Peiró (2005) found that having engaged employees specifically in the service sector can help improve client loyalty and satisfaction, which in turn can lead to organisational profitability. In a study done by Saks (2006), it was found that engaged employees appear to have a relationship with their employer that is of much higher quality which results in those employees having more positive attitudes, intentions, and behaviours towards the organisation and their work. Hakanen, Bakker and Schaufeli (2006) found in a study conducted among teachers that when the teachers were engaged in their work, it ultimately led to organisational commitment. Hence, an engaged employee can yield positive results on both an organisational and individual level.

A model that has been extensively used in research to explain the process of employee wellbeing is the Job Demands-Resources (JD-R) model, which is used to predict the outcomes of engagement and burnout (Demerouti, Bakker, De Jonge, Janssen \& Schaufeli, 2001; Bakker, Demerouti \& Verbeke, 2004, Schaufeli, Bakker \& Van Rhenen, 2009). Even though in every occupation there seems to be different characteristics which will be associated with burnout 
and engagement, these different characteristics can be divided into two broad categories, namely job demands and job resources (Demerouti et al., 2001; Bakker et al., 2004). Job demands refer to those physical, social, or organisational aspects that require sustained physical or mental effort and are therefore associated with certain physiological and psychological costs (Bakker, Demerouti, De Boer \& Schaufeli, 2003; Bakker, Demerouti \& Euwema, 2005; Bakker et al., 2004; Demerouti et al., 2001). In turn, Bakker et al. (2005) state that job resources refer to those physical, psychological, social, or organisational aspects of the job that (a) are functional in achieving work goals, (b) reduce job demands and the associated physiological and psychological costs, or (c) stimulate personal growth and development.

There are two assumptions or processes explained by the JD-R model. The first assumption is that job demands are linked with health impairments (ill health) via the mediating role that burnout plays (Korunka, Kubicek, Schaufeli \& Hoonakker, 2009). Thus high job demands leads to burnout that can eventually cause ill health. This process is referred to as the energetic process (Hakanen, et al., 2006). The second assumption is known as the motivational process (Hakanen et al., 2006). This process assumes that available job resources lead to engagement which in turn can lead to organisational commitment (Korunka, et al., 2009). Understanding the assumptions behind this model can help identify potential problems in the organisation or help keep the employees committed and engaged. To summarise the JD-R model, job demands can be viewed as the main initiators of burnout, which ultimately leads to ill health (energetic process), while sufficient job resources leads to engagement, which could ensure commitment within the organisation (motivational process).

Above and beyond job resources, personal resources tend to also play a significant role in the JD-R model. According to Hobfoll, Johnson, Ennis and Jackson (2003), personal resources are characteristics of an individual which can be related to their resiliency levels. In a study conducted by Xanthopoulou, Bakker, Demerouti and Schaufeli (2007), they concluded that personal resources do play a considerable role in the JD-R model in view of the fact that "together with job demands and job resources, they contribute in explaining variance in exhaustion and work engagement" (p. 137). According to Oginska-Bulik (2005), the enhancement of personal resources is important when developing interventions aimed at reducing stress in the workplace. One of these types of personal resources is sense of 
coherence (SOC). SOC was first introduced by Antonovsky in the 1970s and can be defined as a:

Global orientation that expresses the extent to which one has a pervasive, enduring though dynamic feeling of confidence that (1) the stimuli, deriving from ones internal and external environments in the course of living are structured, predictable and explicable; (2) the resources are available to one to meet the demands posed by these stimuli; and (3) these demands are challenges, worthy of investment and engagement (Antonovsky, 1987, p. 19).

According to Kaiser, Mattsson, Marklund and Wimo (2006), SOC indicates to be a personal resource that comprises of three dimensions, namely, meaningfulness, comprehensibility and manageability. Meaningfulness is "the extent of the belief that coping 'makes sense' emotionally, that one 'wishes to cope'; comprehensibility is 'the extent of the belief that the problem faced by the individual is clear', and manageability is 'the extent of the belief that not only does one understand the problem but the necessary resources to successfully cope with the problem are available" (Richardson, Radner \& Zumbo, 2007, p. 681). These three dimensions are assumed to be developed in the early years of a person's life and seem to be stable from young adulthood onwards. Love, Goh, Hogg, Robson and Irani (2011) concluded that SOC does act as a significant predictor of burnout. They further state that it is therefore believed that an employee's psychological evaluation of their work stressors is an important step in the burnout process. Therefore, it is important to also consider what role personal resources such as SOC can play within the JD-R model.

For organisations to fully utilise their human capital, they have to acknowledge the fact that various factors could play a role in why employees are well or not. One of those factors considered to play a role in some aspects of the employees' well-being, more specifically burnout and engagement, is age (e.g., Conway, 2004; Avery, McKay \& Wilson, 2007; Kaur \& Sandhu, 2010; James, McKechnie, \& Swanberg, 2011). Brewer and Shapard (2004) stated that research has revealed that age and years of experience can be related to burnout. This statement is supported by more recent publications. For example, Ahola, Honkonen, Virtanen, Aromaa and Lönnqvist (2008) found that burnout was much more prevalent in young female workers in Finland, whilst it is almost nonexistent in older female workers. Randall (2007) also supports the previous statement as he found that age was negatively 
correlated to exhaustion and depersonalisation in the ministry. Where SOC is concerned, Antonovsky (1987) stated that SOC seems to be more stable in the later stages of a person's life than in their early childhood years. However, some researcher's findings seemed to contradict Antonovsky's original theory and stated that SOC does not seem to be more stable over time and that there did not seem to be much difference between younger and older employees regarding their SOC levels (Feldt, Leskinen, Kinnunen \& Ruoppila, 2003).

Many reasons exist in literature with regards to why young employees may experience higher levels of burnout such as "reality shock", lack of work experience, new challenges within their lives and transition shock (Ahola et al., 2008; Akkermans, Brenninkmeijer, Blonk \& Koppes, 2009; Ghorpade, Lackritz \& Singh, 2007). Young employees just entering the workforce may find it difficult adjusting to this new phase in their lives since they do not yet possess the relevant experience (Laschinger, Wilk, Cho, \& Greco, 2009). Young employees may also face many challenges and changes during this time of their lives and their wellbeing can either flourish or suffer during this period (Akkermans et al., 2009). This evidence suggests that young employees are more prone to burnout than older employees.

In a study carried out among starting teachers with regards to their engagement, Bakker and Bal (2010) found that on a weekly basis these employees experienced high levels of autonomy, exchange with the supervisor, and opportunities for development, which were positively related to their work engagement and consecutively related to their performance in their job. They therefore found that when these teachers experienced a resourceful working environment, it increased their engagement levels, and consequently resulted in a positive relationship with their performance in their job.

Antoniou, Polychroni and Vlachakis (2006) found that although young employees experience elevated burnout levels, especially where emotional exhaustion and disengagement from their work were concerned, older employees on the other hand seem to experience more elevated levels of stress in terms of the support they received from their government. As a result, younger and older employees seem to both experience certain levels of burnout but perceive it in different ways. When considering engagement and older employees, Avery et al. (2007) found that the satisfaction of older employees with their co-workers seemed to relate significantly to engagement and that older employees seemed to show greater levels of engagement when they were satisfied with their respective co-workers. A more recent study 
conducted by James et al. (2011) also found that older employees tend to experience higher levels of work engagement than younger employees do, but that the job conditions which predicted employee engagement between the age groups did not differ (with the exception of career development and promotion, because it did not seem to be as important to the older employees than it did to the younger employees).

The knowledge of whether age plays a role in the prediction of engagement and burnout by means of job demands and resources as well as personal resources may assist employers to be proactive in their handling of these concepts. Maslach and Leiter (2008) state that having the ability to identify problems in a proactive manner early on can allow for timely preventative solutions within the organisation. Changes related to age such as psychological and cognitive functioning could result in employees becoming less resilient and thus become less adept in handling their job demands, which in turn could lead to burnout and ill health (Hess, 2005; Park et al., 2002). In a study done by Korunka et al., (2009), based on the JD-R model, it was found that although age seems to be invariant across the model, there can be differences across the younger and older employees in what ultimately leads to commitment and ill health. According to Twenge and Campbell (2008), because today's younger employees are indeed different from older employees, it seems to be important to look at the young employees in organisations today.

Today's workforce is very diverse (especially in South Africa) - people are different and they will react differently in certain situations. In particular, age differences with regards to wellbeing are at times overlooked. It is therefore important to investigate the role that age may play in the experience of well-being and the predictors thereof. James et al. (2011) stipulated that the requirements of the younger employees are just as important when considering the well-being of the employees as older employees. However, most of the literature focused more on the well-being of older employees than that of young employees. Korunka et al. (2009) state that, although research has been carried out on the effect of age differences on certain concepts of well-being, little research utilising age as a moderating effect between job demands and job resources with regards to employee well-being has been conducted in previous research. This is especially true within the South African context. This study aimed to address this gap by investigating whether there are significant differences between age groups with regards to burnout and work engagement, and if the job demands, job resources and personal resources predicting burnout and work engagement differ for age groups. This 
study covered a sample of junior managers in the financial sector. Employees in this sector seem to experience high levels of burnout as a result of their work load and working hours (Khattak, Khan, Haq, Arif \& Minhas, 2011). However, not much research was found on work engagement within the financial sector and no studies could be found in the South African context that investigate how burnout and work engagement differ between age groups or that investigate if important predictors (including job demands, job resources and personal resources) are the same for different age groups in the financial sector.

The following research questions can be formulated based on the above mentioned description of the research problem:

- What is the relationship between age, job characteristics (job demands and job resources), burnout and work engagement according to the literature?

- Are there significant differences between young, middle-aged and older employees with regards to their experiences of burnout and work engagement?

- Do the predictors (job demands and job resources, sense of coherence) of burnout and work engagement differ for young, middle-aged and older employees?

- What recommendations can be made for future research regarding the predictors of burnout and work engagement in younger, middle-aged and older employees?

\subsection{RESEARCH OBJECTIVES}

The research objectives are divided into a general objective and specific objectives.

\subsubsection{General objective}

The general objective of this study is to determine if age groups differ in their levels of burnout and work engagement and if predictors of burnout and work engagement differ across the age groups of junior managers in the financial sector.

\subsubsection{Specific objectives}

- To determine the relationship between age, job characteristics (job demands and job resources), burnout, and work engagement, according to the literature. 
- To determine whether there are significant differences between young, middle-aged, and older employees with regards to their experiences of burnout and work engagement.

- To determine whether the predictors (job demands and job resources, sense of coherence) of burnout and work engagement differ for young, middle-aged, and older employees.

- To make recommendations for future research regarding the predictors of burnout and work engagement in younger, middle-aged and older employees.

\subsection{RESEARCH DESIGN}

\subsubsection{Research approach}

This study is of a quantitative nature, which can be defined as a form of conclusive data that spans over a large representative sample (Struwig \& Stead, 2001). This research is crosssectional, which implies that several groups of participants were examined at one point in time (Salkind, 2009).

\subsubsection{Research method}

The research method consists of a literature review and an empirical study. The results are presented in the form of a research article.

\subsubsection{Literature review}

In phase one, a complete literature review was carried out with regards to the JD-R model, job demands, job resources, burnout, work engagement and age. The sources that were consulted included EbscoHost, JStor, Emerald, Science Direct and the Ferdinand Postma Library (NWU Potchefstroom campus). Relevant articles until early 2012 were used.

\subsubsection{Research participants}

The participants consisted of an availability sample of 582 junior managers in the banking industry within South Africa. Participants were divided into three groups, consisting of young 
employees (18-30 years of age), middle-aged employees (31-50 years of age), and older employees (51-65 years of age).

\subsubsection{Measuring instruments}

A biographical questionnaire was utilised to determine the biographical characteristics of the participants. Characteristics such as gender, age, marital status, qualification and home language were measured with this questionnaire.

The South African Employee Health and Wellness Survey (SAEHWS) was administered to collect the data. The SAEHWS is a self-report instrument based on the dual-process model of work-related well-being (Rothmann \& Rothmann, 2006) and is rooted in the assumption that the perceptions and experiences of employees represent imperative information regarding the wellness climate in the organisation. The SAEHWS is valid, reliable, and equivalent for different ethnic groups and organisations and is therefore culturally sensitive with no biasness towards any cultural group (Rothmann \& Rothmann, 2006). The SAEHWS was used to measure the following dimensions namely job characteristics, sense of coherence as well as burnout and work engagement which are discussed in detail below.

Job characteristics. Job pressure was measured by three items (e.g. "Do you have too much work to do?"). Mental load was measured with three items, (e.g. "Do you have to give continuous attention to your work?") and emotional load, also measured by three items (e.g. "Does your work put you in emotionally upsetting situations?"). Perceived organisational support was measured by utilising the sub-facets of the stated definition (colleague support and supervisory relationships, role clarity, job information, participation and decisionmaking). Supervisory support was measured by three items (e.g., "Can you count on your direct supervisor when you come across difficulties?"); colleague support was measured by three items (e.g.,"Can you count on your colleagues when you come across difficulties in your work?"); role clarity was measured by three items (e.g., "Do you know exactly what your responsibilities are?"); job information was measured by three items (e.g., "Do you receive sufficient information on the results of your work?"); and participation in decision making was measured by three items (e.g., "Can you participate in decisions about the nature of your work?"), The overall reliability coefficients are reported as follows (Rothmann \& Rothmann, 2006): Overload (consisting of job pressure, mental load and emotional load) $\alpha=$ 
0,83; social support (consisting of supervisory and colleague support) $\alpha=0,78$; and organisational support $\alpha=0,90$. All demands and resources were measured using a Likert scale ranging from 1 (never) to 4 (always).

Sense of Coherence.SOC was measured by means of 13 items, using a Likert rating response of 0 (never) to 6 (always). A typical question would be: "Do you have the feeling that you don't really care about what goes on around you?" $(\alpha=0,78)$.

Burnout and work engagement. Four dimensions were used to measure work-related wellbeing, including exhaustion (five items, e.g., "I feel tired before I arrive at work", $\alpha=0,83$ ); cynicism (five items, e.g. "I have become less enthusiastic about my work", $\alpha=0,81$ ), vigour (five items, e.g., "I am full of energy in my work", $\alpha=0,80$ ) and dedication (five items, e.g., "I am passionate about my job"; $\alpha=0,86)$. The items were rated on a seven-point Likert rating scale, ranging from 0 (never) to 6 (always).

\subsubsection{Research procedure}

Data was collected over the period of 2010-2011. A letter was sent to participating banks explaining the nature of the study. Permission was granted by all the general managers of the respective banks after which the data was collected. Data was gathered by means of a self report questionnaire which was completed online using a secure website. Informed consent was received from all the participants prior to them completing the questionnaires and before they administered the tests, they were assured that the tests will be kept confidential. To ensure that this project was conducted in an ethical manner, ethical issues such as informed consent, confidentiality and deception were considered (Struwig \& Stead, 2001).

\subsubsection{Statistical analysis}

Statistical analysis was performed using the SPSS programme (SPSS Inc., 2011). Descriptive statistics (means, standard deviations) were employed in the analysis of the data. The Pearson product-moment correlation (Pearson $r$ ) was used to determine the relationship between age, burnout, work engagement, job demands and job resources as well as SOC. This correlation is used to determine the variation of variables between two continuous variables (Struwig \& Stead, 2001). 
Multivariate analysis of variance (MANOVA) was used to determine whether there were differences between the age groups regarding their well-being. MANOVA is a statistical procedure used to determine whether there are any group differences (Salkind, 2009). Analysis of variance (ANOVA) was subsequently used to determine differences for each dimension. If significant differences were found between the age groups, post-hoc analysis was then used in order to establish what specific differences existed between age groups Hierarchical multiple regression analysis was used to determine which job demands and job resources predict burnout and work engagement for different age groups.

\subsection{OVERVIEW OF CHAPTERS}

This mini-dissertation is divided into three chapters. In the first chapter, the problem statement is established and the research design is set out. The second chapter is in the form of a research article containing the results and discussion of the study. Lastly, the third chapter comprises of the conclusion, limitations and recommendations.

\subsection{CHAPTER SUMMARY}

In this chapter, the problem statement was discussed and the research objectives and research design were made clear. An overview of the chapters to follow was provided as well as a summary of this chapter. 


\section{REFERENCES}

Antoniou, A. S., Polychroni, F., \& Vlachakis, A. N. (2006). Gender and age differences in occupational stress and professional burnout between primary and high-school teachers in Greece. Journal of Managerial Psychology, 21(7), 682-690.

Antonovsky, A. (1987). Unraveling the mystery of health. San Fransisco, CA: Jossey-Bass.

Ahola, K., Honkonen, T., Virtanen, M., Aromaa, A., \& Lönnqvist, J. (2008).Burnout in relation to age in the adult working population. Journal of Occupational Health, 50, 362365 .

Akkermans, J., Brenninkmeijer, V., Blonk, R. W. B., \& Koppes, L. L. J. (2009). Fresh and healthy? Well-being, health and performance of young employees with intermediate education. Career Development International, 14(7), 671-699.

Angerer, J. M. (2003). Job burnout. Journal of Employment Counselling, 40, 98-107.

Avery, D. R., McKay, P. F., \& Wilson, D. C. (2007). Engaging the aging workforce: The relationship between perceived age similarity, satisfaction with coworkers, and employee engagement. Journal of Applied Psychology, 92(6), 1542-1556.

Bakker, A. B., Albrecht, S. L., \& Leiter, M. P. (2011). Key questions regarding work engagement. European Journal of Work and Organizational Psychology, 20(1), 4-28.

Bakker, A. B., \& Bal, P. M. (2010). Weekly work engagement and performance: A study among starting teachers. Journal of Occupational and Organizational Psychology, 83, 189-206.

Bakker, A. B., Demerouti, E., \& Euwema, M. C. (2005). Job resources buffer the impact of job demands on burnout. Journal of Occupational Health Psychology, 10(2), 170-180.

Bakker, A. B., Demerouti, E., De Boer, E., \& Schaufeli, W. B. (2003). Job demands and job resources as predictors of absence duration and frequency. Journal of Vocational Behavior, 62, 341-356.

Bakker, A. B., Demerouti, E., \& Verbeke, W. (2004). Using the Job Demands-Resources model to predict burnout and performance. Human Resource Management, 43(1), 83-104.

Bakker, A. B., Hakanen, J. J., Demerouti, E. \& Xanthopoulou. (2007). Job resources boost work engagement, particularly when job demands are high. Journal of Educational Psychology, 99(2), 274-284.

Bakker, A. B., Van Emmerik, H., \& Euwema, M. C. (2006). Crossover of burnout and engagement in work teams. Work and Occupations, 33(4), 464-489. 
Brewer, E. W., \& Shapard, L. (2004). Employee Burnout: A meta-analysis of the relationship between age or years of experience. Human Resource Development Review, 3(2), 102-123.

Conway, E. (2004). Relating career stage to attitudes towards HR practices and commitment: Evidence of interaction effects? European Journal of Work \& Organizational Psychology, $13,417-446$.

Cordes, C. L., \& Dougherty, T. W. (1993). A review and an integration of research on job burnout.The Academy of Management Review, 18(4), 621-656.

De Lange, A. H., De Witte, H., \& Notalaers, G. (2008). Should I stay or should I go? Examining longitudinal relations among job resources and work engagement for stayers versus movers. Work \& Stress, 22(3), 201-223.

Demerouti, E., Bakker, A. B., De Jonge, J., Janssen, P. P. M., \& Schaufeli, W. B. (2001). Burnout and engagement at work as a function of demands and control. Scandinavian Journal Work Environment Health, 27(4), 279-286.

Dikkers, J. S. E., Jansen, P. G. W., De Lange, A. H., Vinkenburg, C. J., \& Kooij, D. (2010). Proactivity, job characteristics, and engagement: A longitudinal study. Career Development International, 15(1), 59-77.

Feldt, T., Leskinen, E., Kinnunen, U., \& Ruoppila, I. (2003). The stability of sense of coherence: Comparing two age groups in a 5-year follow-up study. Personality and Individual Differences, 35, 1151-1165.

Ghorpade, J., Lackritz, J., \& Singh, G. (2007). Burnout and personality: Evidence from academia. Journal of Career Assessment, 15(2), 240-256.

Gruman, J. A., \& Saks, A. M. (2011). Performance management and employee engagement. Human Resource Management Review, 21, 123-136.

Gustavsson, J. P., Hallsten, L., \& Rudman, A. (2010). Early career burnout among nurses: Modelling a hypothesized process using an item response approach. International Journal of Nursing Studies, 47, 864-875.

Hakanen, J. J., Bakker, A. B., \& Schaufeli, W. B. (2006).Burnout and work engagement among teachers. Journal of School Psychology, 43, 495-513.

Hess, T. M. (2005). Memory and aging in context. Psychological Bulletin, 131(3), 383-406.

Hobfoll, S. E., Johnson, R. J., Ennis, N., \& Jackson, A. P. (2003).Resource loss, resource gain, and emotional outcomes among inner city women. Journal of Personality and Social Psychology, 84, 632-643.

James, J. B., McKechnie, S., \& Swanberg, J. (2011).Predicting employee engagement in an age-diverse retail workforce. Journal of Organizational Behavior, 32, 173-196. 
Kaur, K., \& Sandhu, H. S. (2010). Career stage effect on organizational commitment: Empirical evidence from Indian Banking Industry. International Journal of Business and Management, 12(5), 141-152.

Kaiser, P., Mattsson, B., Marklund, S., \& Wimo, A. (2006). Sense of coherence and vocational rehabilitation of persons with chronic musculoskeletal disorders-gender aspects. $J M H G, 3(4), 373-378$.

Khattak, J. K., Khan, M. A., Haq, A. U., Arif, M., \& Minhas, A. A. (2011). Occupational stress and burnout in Pakistan's banking sector. African Journal of Business Management, $5(3), 810-817$.

Korunka, C., Kubicek, B., Schaufeli, W. B., \& Hoonakker, P. (2009). Work engagement and burnout: Testing the robustness of the Job Demands-Resources model. The Journal of Positive Psychology, 4(3), 243-255.

Laschinger, H. K. S., Wilk, P., Cho, J., \& Greco, P. (2009). Empowerment, engagement and perceived effectiveness in nursing environments: Does experience matter? Journal of Nursing Management, 17, 636-646.

Leiter, M. P. (1993). Burnout as a developmental process: Consideration of models. In: W.B. Schaufeli, C. Maslach and T. Marek (Eds.), Professional Burnout, pp. 237-250. Washington, DC: Taylor \& Francis.

Love, P. E. D., Goh, Y. M., Hogg, K., Robson, S., \& Irani, Z. (2011). Burnout and sense of coherence among residential real estate brokers. Safety Science, 49, 1297-1308.

Macey, W. H., \& Schneider, B. (2008).The meaning of employee engagement. Industrial and Organizational Psychology, 1, 3-30.

Maslach, C., Leiter, M. P., \& Schaufeli, W. B. (2008). 'Measuring burnout', In C. L. Coopper\& S. Cartwright (Eds.). The Oxford handbook of organizational well-being (pp. 86-108). Oxford: Oxford University Press.

Maslach, C., \& Leiter, M. P. (2008). Early predictors of job burnout and engagement. Journal of Applied Psychology, 93(3), 498-512.

Maslach, C., Schaufeli, W. B., \& Leiter, M. P. (2001). Job burnout. Annual Review of Psychology, 52, 397-422.

McBain, R. (2006). Employee engagement - the emergence of a new construct? Henley Manager Update, 17(4), 21-32.

Oginska-Bulik, N. (2005). The role of personal and social resources in preventing adverse health outcomes in employees of uniformed professions. International Journal of Occupational Medicine and Environmental Health, 18(3), 233-240. 
Park, D. C., Lautenschlager, G. L., Hedden, T., Davidson, N. S., Smith, A. D., \& Smith, P. K. (2002). Models of visuospatial and verbal memory across the adult life span. Psychology and Aging, 17(2), 299-320.

Randall, K. J. (2007). Examining the relationship between burnout and age among Anglican clergy in England and Wales.Mental. Health, Religion \& Culture, 10(1), 39-46.

Richardson, C. G., Ratner, P. A., \& Zumbo, B. D. (2007). A test of the age-based measurement invariance and temporal stability of Antonovsky's sense of coherence scale. Educational and Psychological Measurement, 67, 679-696.

Rothmann, S. (2003). Burnout and engagement: A South African perspective. SA Journal of Industrial Psychology, 29(4), 16-25.

Rothmann, J. C., \& Rothmann, S. (2006). The South African Employee Health and Wellness Survey: User manual. Potchefstroom: Afriforte (Pty) Ltd.

Saks, A. M. (2006). Antecedents and consequences of employee engagement. Journal of Managerial Psychology, 21(7), 600-619.

Salanova, M., Agut, S., \& Peiró, J. M. (2005). Linking organizational resources and work engagement to employee performance and customer loyalty: The mediation of service climate. Journal of Applied Psychology, 90, 1217-1227.

Salkind, N. J. (2009). Exploring research. (7th ed.). Upper Saddle River, NJ: Pearson Education, Inc.

Schaufeli, W. B., Bakker, A. B., \& Salanova, M. (2006). The measurement of work engagement with a short questionnaire. Educational and Psychological Measurement, 66(4), 701-716.

Schaufeli, W. B., Bakker, A. B., \& Van Rhenen, W. (2009). How changes in job demands and resources predict burnout, work engagement, and sickness absenteeism. Journal of Organizational Behavior, 30, 893-917.

Schaufeli, W. B., Leiter, M. P., \& Maslach, C. (2009). Burnout: 35 years of research and practice. Career Development International, 14(3), 204-220.

Schaufeli, W. B., Salanova, M., González-Romá, V., \& Bakker, A. B. (2002). The measurement of engagement and burnout: A two sample confirmatory factor analytical approach. Journal of Happiness Studies, 3, 71-92.

Seligman, M. E. P., \&Csikszentmihalyi, M. (2000). Positive psychology: An introduction. American Psychologist, 55, 5-14.

SPSS Inc. (2011). SPSS20.0 for Windows.Chicago, IL: SPSS Inc. 
Struwig, F. W., \& Stead, G. B. (2001). Planning, designing and reporting research. Cape Town: Maskew Miller Longman (Pty) Ltd.

Twenge, J. M., \& Campbell, S. M. (2008). Generational differences in psychological traits and their impact on the workplace. Journal of Managerial Psychology, 23(8), 862-877.

Xanthopoulou, D., Bakker, A. B., Demerouti, E. \& Schaufeli, W. B. (2007). The role of personal resources in the job demands-resources model. International Journal of Stress Management, 14(2), 121-141. 
CHAPTER 2

RESEARCH ARTICLE 


\title{
Burnout and work engagement for different age groups: Examining group-level differences and predictors
}

\begin{abstract}
Orientation: Many organisations seem to ignore the important role that age can play in the wellbeing levels of their employees. This is also true of the banking industry, making it important to examine the role of age in burnout and work engagement of junior managers in the financial sector. Research Purpose: To determine whether burnout and engagement levels are experienced differently by young, middle-aged and older workers and if the predictors (job demands, job resources, sense of coherence (SOC)) of burnout and work engagement differ across the three age groups.

Motivation for this study: To indicate the role that age can play in the burnout and work engagement levels of employees.

Research design, approach and method: A cross sectional design method was used in the gathering of the data. The South African Employee, Health and Wellness Survey (SAEHWS) was used to obtain the data in order to identify the well-being levels of the employees across the three age groups as well as the predictors of well-being. The sample was an availability sample $(n=582)$ of junior managers in the financial sector, which was used to determine if there was any group-level differences or predictors across young, middle-aged or older employees.

Main findings: The main findings for this study indicated significant differences across the exhaustion and dedication levels of employees. Predictors varied between the three age groups, although SOC was a consistently significant predictor for burnout and engagement in all three groups. Practical/managerial implications: Organisations need to realise the importance that age can play in the determining and prediction of well-being in their organisations.

Contribution/Value add: The results contribute to both organisations and individuals as they reveal the importance of looking at younger employees as well as older employees with regards to wellbeing. The important role of SOC should be emphasised as well as the fact that different job demands and resources predict burnout and engagement for different age groups.
\end{abstract}

Keywords: Job demands, job resources, burnout, work engagement, Job Demands-Resources (JD-R) Model, age, sense of coherence (SOC) 


\section{INTRODUCTION}

Well-being is regarded as an important concept to consider when investigating employees' welfare (e.g. Akkermans, Brenninkmeijer, Blonk \& Koppes, 2009; Cooper, 2005; Hansson, Hilleras \& Forsell, 2005). The well-being of employees in the workplace ought to be seen as a very important concept in any organisation. Knowing whether employees within an organisation are well or not, can be the difference between having a successful or failing business (Baptiste, 2008). In related literature, two concepts of well-being that are widely researched are burnout and work engagement (Schaufeli, Salanova, González-Romá \& Bakker, 2002).

Burnout is a term that uniformly has strong negative connotations in all occupations. Burnout can be described as the end result of an imbalance that exists between job demands and resources within the employees' workplace, it is thus a reaction to delayed stress that develops over time as a result of that imbalance (Kalimo, Pahkin, Mutanen \& ToppinenTanner, 2003). Research has shown that when signs of burnout are ignored, it can lead to other negative outcomes, which can include, but are not limited to, absenteeism, intention to leave the organisation, job dissatisfaction, and turnover intention (Maslach \& Leiter, 2008; Visser \& Rothmann, 2008). Burnout also has negative consequences for the individual, which can include, for example, depression as well as chronic fatigue, which affects the individual's performance as a result of prolonged burnout (Bakker, Van Emmerik \& Euwema, 2006; Hakanen, Shaufeli \& Ahola, 2008). Many studies have also identified that employees with high levels of burnout tend to demonstrate negative attitudes such as stereotyping, cynicism or reduced empathy towards both clients and the organisation (Westman \& Bakker, 2008). It is therefore of importance to monitor burnout levels as well as to determine important predictors thereof within the organisation.

Work engagement is viewed as the positive antipode of burnout. Having an engaged workforce, could result in employees having relationships of much higher quality with that organisation. This ultimately leads to positive attitudes, intentions and behaviours towards their organisation (Saks, 2006). On an emotional level, employees appear to be more attached to the organisation when they experience high levels of engagement which in turn leads to those employees performing their job with more passion and thus ensuring greater success for 
that company as well (Markos \& Sridevi, 2010). According to Bakker and Demerouti (2008), an engaged employee within the organisation can experience positive emotions such as joy, happiness and enthusiasm as well as better health. They can create their own job and personal resources and ultimately transfer their engagement onto their colleagues. Consequently it can be seen why research has indicated how engagement can and does have a positive outcome on both an organisational as well as an individual level (Bakker, Hakanen, Demerouti \& Xanthopoulou, 2007).

Many researchers emphasise the fact that there are certain demographic factors that can play a role in the development of burnout or work engagement (e.g., Antoniou, Polychroni \& Vlachakis, 2006; Garner, Knight \& Simpson, 2007). More specifically, age seems to play an important role in burnout or engagement levels (Akkermans et al. 2009; Garner et al, 2007). Different studies have emerged in the past few years, which have concluded that age does play a role in the well-being of employees. For example, older workers seem to experience higher levels of engagement than younger workers do (James, McKechnie \& Swanberg, 2011), whereas the younger workforce seems to experience higher levels of burnout than their older counterparts (e.g., Jackson \& Rothmann, 2005; Randall, 2007). Similarly, literature also suggests that there may be different predictors that can have an influence on burnout and work engagement in older and younger employees. These predictors include job characteristics that is, job demands and resources, and personal resources such as sense of coherence (Kalimo et al., 2003; Korunka, Kubicek, Schaufeli \& Hoonakker, 2009). However, age does not seem to facilitate the predictors of burnout and engagement (Korunka et al., 2009).

James et al. (2011) state that the well-being of younger employees is just as important to consider as the well-being of older employees is. The majority of literature findings however focus on the well-being of older employees, ignoring the well-being of younger employees to a large extent. This scenario also seems to exist within the South African context. Employees in the financial sector have been found to experience high levels of burnout as a result of their demanding work due to a decline in their job resources and an increase in their job demands (Ten Brummelhuis, Ter Hoeven, Bakker \& Peper, 2011). More specifically, employees in the banking sector seem to experience high levels of burnout as a result of their work load and working hours (Khattak, Khan, Haq, Arif \& Minhas, 2011). However, little research was found on work engagement within the financial sector. Few studies could be found that 
investigate burnout and work engagement differences between age groups in the South African context, or that investigate if important predictors (including job demands, job resources and personal resources) are the same for different age groups in the financial sector. Based on the above discussion, this study aims to 1) determine if age groups in the financial sector differ in their levels of burnout and work engagement; and 2) to determine if a particular prediction model (including job demands, job resources and personal resources) is different for different age groups.

\section{LITERATURE REVIEW}

\section{Burnout and work engagement}

Burnout can be defined as "a psychological syndrome in response to chronic interpersonal stressors on the job" (Maslach, Schaufeli, \& Leiter, 2001, p. 399). Burnout, as defined, comprises of three dimensions, namely exhaustion, cynicism and reduced personal efficacy (Maslach et al., 2001). These three dimensions can be explained as when employees experiences extensive levels of exhaustion to such an extent that they cannot function optimally within their job (exhaustion), a detachment from the job because of a lack of meaning attached to the work (cynicism) and a reduced feeling of success or achievement within the job (reduced personal efficacy) (Maslach et al., 2001). Although literature does confirm burnout to be a three-factor model, exhaustion and cynicism are regarded as the two core concepts of burnout, while reduced personal efficacy is seen as a characteristic of a person's personality and seems to develop parallel to and not sequentially to exhaustion and cynicism (Cordes \& Dougherty, 1993; Leiter, 1993). As a result, many studies include only exhaustion and cynicism when studying the effects of burnout (e.g. Patrick \& Lavery, 2007).

Work engagement can be defined as "a positive, fulfilling, work-related state of mind that is characterised by vigour, dedication, and absorption" (Schaufeli et al., 2002, p. 74). Vigour is characterised by very high levels of energy experienced within the work place as well as an enthusiasm within themselves to perform their job the best way they know how, regardless of any downfalls which may occur. When an employee experiences a sense of "significance, enthusiasm, inspiration, pride and challenge" within their job environment, it is known as dedication; while absorption is characterised by an employee's motivation within their work when they tend to be so absorbed in their job that they may have a propensity to lose track of 
time and as a result do not detach easily from their job (Schaufeli et al., 2002, p. 74). Similarly, as with burnout, many researchers also only include the two core concepts, namely vigour and dedication, in their studies, leaving out the third of absorption (Rothmann \& Joubert, 2007). According to Schaufeli et al. (2002), absorption as well as reduced personal efficacy, are not end points on a continuum, but rather two very different facets. For this reason, absorption and reduced personal efficacy will be excluded from the current study as well.

\section{Age, burnout and work engagement}

Employees of all ages are included in the workforce of organisations and are therefore in different phases of their careers, ranging from entry level employees (young adulthood) to employees that have reached retirement age (James et al., 2011). Today's workplace is very diverse as it has changed a great deal over the past few years and South African organisations are no exception (Van der Walt \& Du Plessis, 2010). A number of studies have established that age does seem to play a role in the burnout and engagement levels of employees (e.g., Garner et al.,; James et al., 2011).

Research on burnout and age across a range of occupations (e.g., nursing and teaching professions) all seem to yield the same results - that is, that younger employees seem to experience higher levels of burnout than their older colleagues (e.g., Antoniou et al.,2006; Brewer \& Shapard, 2004). Randall (2007) found in their study among the Anglican clergy that age was indeed negatively correlated to exhaustion and cynicism when looking at younger ministers. Patrick and Lavery (2007) also found that older nurses' levels of burnout seemed to decrease as they got older. In South Africa, Jackson and Rothmann (2005) reached the same conclusion namely, that older workers in the education profession exhibited lower levels of burnout when compared to younger educators. Burnout therefore appears to develop in the early career stage of employees and consequently seems to be more prevalent in younger employees than in older employees.

Possible reasons for younger employees' higher burnout levels seem to include a lack of skills to deal with everyday problems arising in the workplace, a "reality shock" when just entering the workplace, a lack of coping skills as result of less experience in a working environment and transitional shock (Ahola et al., 2006; Duchscher, 2009; Ghorpade, Lackritz \& Singh, 2007; Patrick \& Lavery, 2007). Based on the above argument, it is expected that in 
South Africa, young employees in the banking industry will also display higher levels of burnout than middle-aged or older employees. The following hypothesis can be formulated:

$\mathrm{H}_{1}$ : Young employees will experience higher levels of burnout compared to their middle-aged or older counterparts.

Concerning the issue of work engagement, the opposite seems to be true. Studies have concluded that older workers seem to be more likely to have higher levels of engagement than younger or middle aged employees (e.g., James et al., 2011; Pitt-Catsouphes \& MatzCosta, 2008). James et al. (2011) found that in a large sample of employees in a retail setting, older workers displayed much higher levels of engagement than their younger equivalents. Schaufeli, Bakker and Salanova (2006) however found that engagement increases with age only to a limited extent. Laschinger, Wilk, Cho and Greco (2009) found in their research that newly graduated employees entering the workforce seem more likely to experience lower levels of engagement as a result of their limited experience, which can result in them having less personal resources to deal with the demands of the workplace. It can therefore be said that there is a great need for organisations to ensure they understand the importance of considering younger employees when taking the well-being of their staff into account (Akkermans et al., 2009). From literature, there is support for the notion that older employees will exhibit higher levels of engagement than middle aged and younger workers. The following hypothesis can therefore be formulated, based on the literature:

$\mathrm{H}_{2}$ : Older employees will experience higher levels of engagement compared to their middle-aged or younger counterparts.

\section{The Job Demands-Resources model and personal resources}

In order to explain how the process of employee well-being (engagement and burnout) works, the Job Demands-Resource (JD-R) model is regularly used to aid in the explanation. It is a heuristic model that states how two processes are monitored by two working conditions, namely job demands and job resources (Bakker, Demerouti \& Schaufeli, 2003). Bakker et al. (2003) define job demands as "those physical, social, or organisational aspects of the job that require sustained physical and/or psychological (i.e., cognitive or emotional) effort on the part of the employee and are therefore associated with certain physiological and/or psychological costs (e.g., exhaustion)" (p. 395). Job resources are therefore represented by 
any characteristic connected to the job that can have a negative impact on the employee. Job resources on the other hand, are defined as "those physical, psychological, social, or organisational aspects of the job that (a) are functional in achieving work goals, (b) reduce job demands and the associated physiological and psychological costs, or (c) stimulate personal growth and development" (Bakker, Demerouti \& Euwema, 2005, p. 170).

The JD-R model consists of two processes, namely the energetic process and the motivational process. Briefly explained, the energetic process connects job demands via burnout with health impairments, while the motivational process connects job resources to organisational commitment via work engagement (Shaufeli \& Bakker, 2004). Therefore, having continuously high job demands such as high work pressure and emotional demands ultimately predicts or leads to burnout and exhaustion over the long term (Bakker et al., 2003; Bakker, Demerouti \& Verbeke, 2004). On the other hand, ensuring high job resources to meet those demands such as autonomy, social support, job clarity and supervisory support, to name just a few, can ultimately predict work engagement and commitment within the organisation (Bakker et al., 2006; James et al., 2011).

According to Hakanen, Bakker and Schaufeli (2006), their results on a sample of teachers specifically showed that job resources have a "dual role", meaning that when employees are able to utilise the job resources available to them to meet their demands, it might result in them showing higher levels of vigour and dedication towards their organisation which can result in higher organisational commitment. Having sufficient job resources will accordingly assist employees in dealing with their job demands more efficiently and effectively in order to ultimately ensure commitment towards the organisation. However, other than burnout and engagement in itself, age does not appear to have an effect on the predictors of burnout and engagement in younger, middle-aged or older workers. In the study conducted by Korunka et al. (2009) regarding age and the JD-R model, for example, age seemed to be invariant across the model. James et al. (2011) supported this notion as they too found that although the wellbeing of younger and older workers did differ across age; with exception of career development and promotion the predictors of well-being did not differ. As age seems to be invariant across the predictors of burnout and engagement, the following hypothesis for the South African context in the banking industry is formed: 
$\mathrm{H}_{3 \mathrm{a}}$ : Job demands which predict burnout and work engagement will not differ for the different age groups.

$\mathrm{H}_{3 \mathrm{~b}}$ : Job resources which predict burnout and work engagement will not differ for the different age groups.

Bakker et al. (2008) stated in their review article of work engagement, that engagement is best predicted not only by job resources but also by personal resources. Personal resources play a considerable role within the JD-R model as they appear to contribute to the variance explained in exhaustion and engagement (Xanthopoulou, Bakker Demerouti \& Schaufeli, 2007). Kalimo et al., (2003) found in their research that sense of coherence (SOC) seemed to be the most important personal resource in their study of burnout predictors. The concept of SOC was first introduced by Antonovsky $(1979,1987)$ who stated that this construct is a "stress resistant resource", which protects the employee from the harmful effects that negative stressors may have on their well-being and ultimately helps to improve that wellbeing. In support of this, for example, Van der Colff and Rothmann (2009) found in their study amongst registered nurses in South Africa that a strong SOC predicted work engagement.

Where age and SOC are concerned, Antonovsky (1987) proposed that in theory SOC will develop over an individual's life span and will stabilise by the age of 30, only changing if circumstances of the individual's life changes dramatically. However, Feldt, Leskinen, Kinnunen and Ruoppila (2003) tested Antonovsky's theory over a span of five years and found that older employees did not differ in their stability of SOC from younger employees. Age, on the contrary, did not seem to be a factor in the "stability, level or mean changes" in SOC (Feldt et al., 2003). Currently no research was found on how SOC and age can be correlated in South Africa and therefore the last hypothesis is formulated as follows for the South African context:

$\mathrm{H}_{4}$ : Junior managers in the banking industry will not differ in their SOC levels across the different age groups. 


\section{RESEARCH DESIGN}

\section{Research approach}

This nature of this study was quantitative, which can be defined as a form of conclusive data that spans a large representative sample (Struwig \& Stead, 2001). This research was crosssectional, which implies that several groups of participants were examined at one point in time (Salkind, 2009).

\section{Research method}

\section{Research participants}

The participants consisted of an availability sample of 582 junior managers in the banking industry within South Africa. Participants were divided into three groups, which consisted of young employees (18-30 years of age), middle-aged employees (31-50 years of age) and older employees (51-65 years of age). The characteristics of the participants are indicated in Table 1. 


\section{Table 1}

Characteristics of Participants

\begin{tabular}{|c|c|c|c|}
\hline Item & Category & Frequency & Percentage (\%) \\
\hline \multirow[t]{2}{*}{ Gender } & Male & 259 & 44,50 \\
\hline & Female & 323 & 55,50 \\
\hline \multirow[t]{3}{*}{ Age } & Young & 134 & 23,00 \\
\hline & Middle & 280 & 48,10 \\
\hline & Old & 168 & 28,90 \\
\hline \multirow[t]{5}{*}{ Marital Status } & Single & 152 & 26,10 \\
\hline & Engaged & 13 & 2,20 \\
\hline & Married & 336 & 57,70 \\
\hline & Divorced & 69 & 11,90 \\
\hline & Widow & 12 & 2,10 \\
\hline \multirow[t]{8}{*}{ Qualification } & Grade 9 & 3 & 0,50 \\
\hline & Grade 10 & 15 & 2,60 \\
\hline & Grade 11 & 7 & 1,20 \\
\hline & Grade 12 & 225 & 38,70 \\
\hline & 3 Year Degree/Diploma & 177 & 30,40 \\
\hline & 4 Year Degree/Diploma & 100 & 17,20 \\
\hline & 5 to 7 Year Degree & 26 & 4,50 \\
\hline & Master's Degree & 29 & 5,00 \\
\hline \multirow[t]{9}{*}{ Province } & Gauteng & 448 & 77,00 \\
\hline & Mpumalanga & 8 & 1,40 \\
\hline & North West Province & 5 & 0,90 \\
\hline & Limpopo & 1 & 0,20 \\
\hline & Free State & 14 & 2,40 \\
\hline & Northern Cape & 2 & 0,30 \\
\hline & Western Cape & 54 & 9,30 \\
\hline & Eastern Cape & 12 & 2,10 \\
\hline & Kwa-Zulu Natal & 38 & 6,50 \\
\hline \multirow[t]{12}{*}{ Home Language } & Afrikaans & 193 & 33,20 \\
\hline & English & 315 & 54,10 \\
\hline & Sepedi & 8 & 1,40 \\
\hline & Sesotho & 13 & 2,20 \\
\hline & Setswana & 17 & 2,90 \\
\hline & Siswati & 3 & 0,50 \\
\hline & Tshivenda & 1 & 0,20 \\
\hline & isiZulu & 16 & 2,70 \\
\hline & isiNdebele & 2 & 0,30 \\
\hline & isiXhosa & 8 & 1,40 \\
\hline & Xitsonga & 3 & 0,50 \\
\hline & Other & 3 & 0,50 \\
\hline
\end{tabular}


The participants were a representation of all nine provinces and comprised mostly of female participants $(55,50 \%)$ who resided in the Gauteng province $(77.00 \%)$. The majority of the participants were in the middle-aged, 31-50 years old group $(48,10 \%)$ and were married $(57,70 \%)$. With regard to formal qualifications, $38,70 \%$ of the participants obtained a Grade 12 qualification or a three-year Degree/Diploma (30,40\%).

\section{Measuring instruments}

A biographical questionnaire was utilised to determine the biographical characteristics of the participants. Characteristics such as gender, age, marital status, qualification and home language were measured with this questionnaire. The South African Employee Health and Wellness Survey (SAEHWS) was administered to collect the data regarding the well-being of the employees. The SAEHWS is a self-report instrument based on the dual-process model of work-related well-being (Rothmann \& Rothmann, 2006) and is rooted in the assumption that employees' perceptions and experiences represent imperative information regarding the wellness climate in the organisation. The SAEHWS is valid, reliable and equivalent for different ethnic groups and organisations and is therefore culturally sensitive, displaying no bias against any cultural group (Rothmann \& Rothmann, 2006). The SAEHWS was used to measure the following dimensions namely job characteristics, sense of coherence as well as burnout and work engagement which are discussed in detail below.

Job characteristics. Job pressure was measured by three items (e.g. "Do you have too much work to do?"). Mental load was measured with three items, (e.g. "Do you have to give continuous attention to your work?") and emotional load also by three items (e.g. "Does your work put you in emotionally upsetting situations?"). Perceived organisational support was measured by utilising the sub-facets of the stated definition (colleague support, and supervisory support, role clarity, job information, participation in decision-making): Supervisory support was measured by three items (e.g."Can you count on your direct supervisor when you come across difficulties?"); Colleague support was measured by three items (e.g. "Can you count on your colleagues when you come across difficulties in your work?"); Role clarity was measured by three items (e.g. "Do you know exactly what your responsibilities are?"); Job information was measured by three items (e.g. "Do you receive sufficient information on the results of your work?"); and Participation in decision making was measured by three items (e.g. "Can you participate in decisions about the nature of your work?”), 
The overall reliability coefficients are reported as follows (Rothmann \& Rothmann, 2006): Overload (consisting of job pressure, mental load and emotional load) $\alpha=0,83$; social support (consisting of supervisory and colleague support) $\alpha=0,78$; and organisational support $\alpha=0,90$. All demands and resources were measured with a Likert scale ranging from 1 (never) to 4 (always).

Sense of Coherence. SOC was measured by means of 13 items, using a Likert rating response of 0 (never) to 6 (always). A typical question would be: "Do you have the feeling that you don't really care about what goes on around you?" $(\alpha=0,78)$.

Burnout and work engagement. Four dimensions were used to measure work-related wellbeing, including exhaustion (five items, e.g. "I feel tired before I arrive at work", $\alpha=0,83$ ); cynicism (five items, e.g. "I have become less enthusiastic about my work", $\alpha=0,81$ ), vigour (five items, e.g. "I am full of energy in my work", $\alpha=0,80$ ) and dedication (five items, e.g. "I am passionate about my job"; $\alpha=0,86$ ). The items were rated on a seven-point Likert rating scale, ranging from 0 (never) to 6 (always).

\section{Research procedure}

Data were collected over the period of 2010-2011. A letter was sent to participating banks explaining the nature of the study. Permission was granted by all the general managers from the respective banks, after which the data were then collected. Data were gathered by means of a self report questionnaire which was completed online using a secure website. Informed consent was received from all the participants prior to them completing the questionnaires and before the tests were administered the participants was assured that the questionnaires would be kept confidential. To ensure that this project was conducted in an ethical manner, ethical issues such as informed consent, confidentiality and deception were considered (Struwig \& Stead, 2001).

\section{Statistical analysis}

Statistical analysis was done using the SPSS programme (SPSS Inc., 2011). Descriptive statistics (means, standard deviations) were used in the analysis of the data. The Pearson product-moment correlation (Pearson $r$ ) which is used to determine the variation of variables between two continuous variables (Struwig \& Stead, 2001), was used to determine the 
relationship between age, burnout, work engagement, job demands and job resources as well as SOC.

Multivariate analysis of variance (MANOVA) was used to determine whether there were differences between the age groups regarding their well-being. MANOVA's is a statistical procedure used to determine whether there are any group differences (Salkind, 2009). Analysis of variance (ANOVA) was then used to determine differences for each dimension. If significant differences were found between age groups, post-hoc analysis was then used in order to establish what specific differences existed between age groups. Hierarchical multiple regression analysis was used to determine which job demands, job resources and personal resources predict burnout and work engagement for different age groups.

\section{RESULTS}

Descriptive statistics and reliability, as well as the correlations between the dimensions are reported in Table 2 below. 
Table 2

Descriptive Statistics, Cronbach Alpha Coefficients of the Measuring Instruments and Correlation Coefficients

\begin{tabular}{|c|c|c|c|c|c|c|c|c|c|c|c|c|c|c|c|}
\hline Item & Mean & SD & $\alpha$ & 1 & 2 & 3 & 4 & 5 & 6 & 7 & 8 & 9 & 10 & 11 & 12 \\
\hline 1. Job pressure & 7,85 & 2,21 & 0,77 & & & & & & & & & & & & \\
\hline 2. Mental load & 9,56 & 2,12 & 0,79 & $0,63^{+* *}$ & & & & & & & & & & & \\
\hline 3. Emotional load & 7,10 & 2,12 & 0,72 & $0,41^{+*}$ & $0,41^{+^{*}}$ & & & & & & & & & & \\
\hline 4. Supervisor support & 9,05 & 2,41 & 0,81 & $-0,10^{+}$ & $-0,04$ & $-0,26^{+}$ & & & & & & & & & \\
\hline 5. Colleague support & 9,16 & 1,95 & 0,83 & $-0,19^{+}$ & $-0,12^{+}$ & $-0,27^{+}$ & $0,51^{+* * *}$ & & & & & & & & \\
\hline 6. Role clarity & 9,29 & 1,96 & 0,79 & $-0,04$ & 0,07 & $-0,14^{+}$ & $0,61^{+* * *}$ & $0,39^{+*}$ & & & & & & & \\
\hline 7. Job information & 8,52 & 2,23 & 0,74 & $-0,04$ & 0,08 & $-0,12^{+}$ & $0,65^{+* *}$ & $0,40^{+*}$ & $0,78^{+* *}$ & & & & & & \\
\hline 8. Participation in decision making & 8,61 & 2,25 & 0,84 & $-0,07$ & 0,01 & $-0,19^{+}$ & $0,71^{+* *}$ & $0,45^{+*}$ & $0,61^{+* * *}$ & $0,66^{+* *}$ & & & & & \\
\hline 9. Sense of coherence & 60,40 & 12,81 & 0,76 & $-0,19^{+}$ & $-0,12^{+}$ & $-0,33^{+*}$ & $0,35^{+*}$ & $0,31^{+*}$ & $0,33^{+*}$ & $0,32^{+*}$ & $0,38^{+*}$ & & & & \\
\hline 10. Exhaustion & 14,45 & 6,44 & 0,89 & $0,39^{+*}$ & $0,32^{+*}$ & $0,45^{+*}$ & $-0,33^{+*}$ & $-0,32^{+*}$ & $-0,23^{+}$ & $-0,20^{+}$ & $-0,28^{+}$ & $-0,53^{+* *}$ & & & \\
\hline 11. Cynicism & 8,08 & 5,40 & 0,86 & $0,12^{+}$ & 0,02 & $0,31^{+*}$ & $-0,39^{+*}$ & $-0,34^{+*}$ & $-0,37^{+*}$ & $-0,34^{+*}$ & $-0,42^{+*}$ & $-0,51^{+* *}$ & $0,52^{+* * *}$ & & \\
\hline 12. Vigour & 20,68 & 5,19 & 0,84 & $-0,14^{+}$ & $-0,04$ & $-0,31^{+^{*}}$ & $0,42^{+*}$ & $0,38^{+^{*}}$ & $0,31^{+^{*}}$ & $0,34^{+^{*}}$ & $0,42^{+^{*}}$ & $0,54^{+* *}$ & $-0,59^{+* * *}$ & $-0,67^{+* * *}$ & \\
\hline 13. Dedication & 21,70 & 5,86 & 0,88 & 0,08 & $0,11^{+}$ & $-0,18^{+}$ & $0,41^{+*}$ & $0,32^{+*}$ & $0,36^{+*}$ & $0,38^{+*}$ & $0,45^{+^{*}}$ & $0,48^{+*}$ & $-0,35^{+*}$ & $-0,73^{+* *}$ & $0,78^{+* *}$ \\
\hline
\end{tabular}

${ }^{+}$Statistically significant $(p \leq 0,05)$

* Correlation is practically significant $r \geq 0,30$ (medium effect)

** Correlation is practically significant $r \geq 0,50$ (large effect) 
Table 2 shows acceptable Cronbach Alpha coefficients for all the dimensions - all the alpha's were higher than the proposed guideline of $\alpha \geq 0,70$ (Nunnally \& Bernstein, 1994). In addition, Table 2 also provides the correlations of the variables being studied. Cynicism and vigour were statistically significantly related to job pressure. Exhaustion was statistically and practically related, with a medium effect, to job pressure and mental load. Dedication was statistically significantly related to mental load. Exhaustion, cynicism and vigour were statistically and practically related, with a medium effect, to emotional load, while dedication was only statistically significantly related to emotional load. Exhaustion, cynicism, vigour and dedication were all statistically and practically related, with a medium effect, to supervisory support, colleague support, role clarity, job information and participation in decision making with the exception of exhaustion, which was only statistically significantly related to role clarity, job information and participation in decision making. Exhaustion, cynicism and vigour are statistically and practically related, to a large effect, to SOC, whereas dedication is only statistically and practically related, to a medium effect, to SOC.

Following this, MANOVAs were used to determine the differences between age and burnout (exhaustion and cynicism) and work engagement (vigour and dedication). The analysis of the Wilks' Lambda values showed that there were indeed statistically significant differences $(F(8,1152)=2,09 ; p=0,03$, with partial eta squared $=0,01)$ (differences are significant at $p$ $\leq 0,05$ level) between the age groups regarding burnout and work engagement. Specific differences were analysed further using ANOVA. As a result of the differing sizes of the samples, the Games-Howell procedure was used in order to determine whether there were any statistically significant differences between the age groups. The results of the ANOVA analysis are presented in Table 3 below.

Table 3

ANOVA - Differences in Burnout Based on Age

\begin{tabular}{lccccc}
\hline Variable & $\begin{array}{c}\text { Young } \\
\text { employees }\end{array}$ & $\begin{array}{c}\text { Middle aged } \\
\text { employees }\end{array}$ & $\begin{array}{c}\text { Older } \\
\text { employees }\end{array}$ & $\boldsymbol{p}$ & $\begin{array}{c}\text { Partial Eta } \\
\text { Squared }\end{array}$ \\
\hline Exhaustion & $15,25^{\mathrm{a}}$ & $14,97^{\mathrm{a}}$ & $12,95^{\mathrm{b}}$ & $0,00^{*}$ & 0,02 \\
Cynicism & 8,70 & 8,20 & 7,38 & 0,09 & 0,01 \\
Vigour & 20,04 & 20,59 & 21,36 & 0,08 & 0,01 \\
Dedication & $20,79^{\mathrm{a}}$ & 21,73 & $22,38^{\mathrm{b}}$ & 0,06 & 0,01 \\
\hline
\end{tabular}

* Statistically significant difference: $p \leq 0,05$; Means with different superscripts differed significantly at $p \leq 0,05$ 
As illustrated by Table 3, the three age groups experienced significantly different levels of exhaustion $(p \leq 0,05)$, where young and middle-aged employees seemed to experience the highest levels of exhaustion and older employees the lowest exhaustion levels. However, no significant differences were found for cynicism. Therefore, Hypothesis 1 is partially accepted. Furthermore, although the $p$-values for vigour and dedication were $\geq 0,05$, the posthoc analysis did show significant differences for dedication between young and older employees, with younger employees experiencing significantly lower levels of dedication compared to older employees. Partial support was therefore found for Hypothesis 2.

In order to establish which predictors (job demands, job resources, SOC) significantly predicted burnout and engagement across the three age groups, hierarchical multiple regression analysis was used. The results of the regression analysis are illustrated in Tables 4, 5, 6 and 7 and a summary of all the significant findings across the age groups is illustrated in Table 8. 
Table 4

Hierarchical Multiple Regression Analysis with Exhaustion as Dependent Variable

\begin{tabular}{|c|c|c|c|c|c|c|c|c|c|c|c|c|c|}
\hline \multirow[t]{2}{*}{ Model } & & $\underset{\beta}{\text { Standardised }}$ & $t$ & $p$ & $R^{2}$ & $\underset{\beta}{\text { Standardised }}$ & $t$ & $p$ & $R^{2}$ & $\underset{\beta}{\text { Standardised }}$ & $t$ & $p$ & $R^{2}$ \\
\hline & & \multicolumn{4}{|c|}{ Young } & \multicolumn{4}{|c|}{ Middle-aged } & \multicolumn{4}{|c|}{ Old } \\
\hline \multirow[t]{4}{*}{1} & (Constant) & & 1,84 & 0,07 & 0,24 & & 1,74 & 0,08 & 0,25 & & $-2,63$ & 0,01 & 0,33 \\
\hline & Job pressure & 0,27 & 2,53 & $0,01^{* *}$ & & 0,29 & 4,22 & $0,00^{* *}$ & & 0,08 & 0,96 & 0,34 & \\
\hline & Mental load & $-0,07$ & $-0,61$ & 0,54 & & $-0,06$ & $-0,85$ & 0,39 & & 0,28 & 3,59 & $0,00^{* *}$ & \\
\hline & Emotional load & 0,36 & 4,10 & $0,00^{* *}$ & & 0,34 & 5,96 & $0,00^{* *}$ & & 0,34 & 4,62 & $0,00^{* *}$ & \\
\hline \multirow[t]{9}{*}{2} & (Constant) & & 3,89 & 0,00 & 0,32 & & 4,30 & 0,00 & 0,31 & & 1,44 & 0,15 & 0,40 \\
\hline & Job pressure & 0,24 & 2,27 & $0,03^{*}$ & & 0,28 & 4,19 & $0,00^{* *}$ & & 0,06 & 0,71 & 0,48 & \\
\hline & Mental load & $-0,03$ & $-0,27$ & 0,79 & & $-0,02$ & $-0,23$ & 0,82 & & 0,30 & 3,86 & $0,00^{* * *}$ & \\
\hline & Emotional load & 0,33 & 3,79 & $0,00^{* *}$ & & 0,25 & 4,29 & $0,00^{* *}$ & & 0,24 & 3,16 & $0,00^{* *}$ & \\
\hline & Supervisor support & 0,04 & 0,32 & 0,75 & & $-0,20$ & $-2,35$ & $0,02^{*}$ & & $-0,17$ & $-1,65$ & 0,10 & \\
\hline & Colleague support & $-0,14$ & $-1,58$ & 0,12 & & $-0,04$ & $-0,61$ & 0,54 & & $-0,21$ & $-2,70$ & $0,01^{* *}$ & \\
\hline & Role Clarity & $-0,09$ & $-0,79$ & 0,43 & & $-0,10$ & $-1,16$ & 0,25 & & 0,04 & 0,39 & 0,70 & \\
\hline & Job information & $-0,00$ & $-0,02$ & 0,99 & & 0,13 & 1,39 & 0,17 & & $-0,03$ & $-0,32$ & 0,75 & \\
\hline & Participation in decision making & $-0,18$ & $-1,67$ & 0,10 & & $-0,07$ & $-0,83$ & 0,41 & & 0,06 & 0,66 & 0,51 & \\
\hline \multirow[t]{4}{*}{3} & (Constant) & & 5,15 & 0,00 & 0,37 & & 7,18 & 0,00 & 0,41 & & 4,50 & 0,00 & 0,55 \\
\hline & Job pressure & 0,21 & 2,10 & $0,04^{*}$ & & 0,27 & 4,25 & $0,00^{* *}$ & & 0,05 & 0,75 & 0,46 & \\
\hline & Mental load & $-0,02$ & $-0,22$ & 0,83 & & $-0,02$ & $-0,28$ & 0,78 & & 0,30 & 4,38 & $0,00^{* *}$ & \\
\hline & Emotional load & 0,25 & 2,84 & $0,01^{* *}$ & & 0,18 & 3,29 & $0,00^{* *}$ & & 0,15 & 2,21 & $0,03^{*}$ & \\
\hline
\end{tabular}

${ }^{* * *}$ Statistically significant $p \leq 0,01$

${ }^{*}$ Statistically significant $p \leq 0,05$ 
Table 4 continued

Hierarchical Multiple Regression Analysis with Exhaustion as Dependent Variable

\begin{tabular}{|c|c|c|c|c|c|c|c|c|c|c|c|c|c|}
\hline \multicolumn{2}{|c|}{ Model } & $\begin{array}{c}\text { Standardised } \\
\beta\end{array}$ & $t$ & $p$ & $R^{2}$ & $\underset{\beta}{\text { Standardised }}$ & $t$ & $p$ & $R^{2}$ & $\underset{\beta}{\text { Standardised }}$ & $t$ & $p$ & $\boldsymbol{R}^{2}$ \\
\hline & & \multicolumn{4}{|c|}{ Young } & \multicolumn{4}{|c|}{ Middle-aged } & \multicolumn{4}{|c|}{ Old } \\
\hline \multirow[t]{6}{*}{3} & Supervisor support & 0,06 & 0,54 & 0,59 & & $-0,17$ & $-2,16$ & $0,03^{*}$ & & -0.23 & $-2,55$ & $0,01^{* * *}$ & \\
\hline & Colleague support & $-0,13$ & $-1,51$ & 0,13 & & $-0,03$ & $-0,48$ & 0,63 & & -0.10 & $-1,42$ & 0,16 & \\
\hline & Role Clarity & $-0,12$ & $-1,09$ & 0,28 & & $-0,04$ & $-0,44$ & 0,66 & & 0.11 & 1,34 & 0,18 & \\
\hline & Job information & 0,04 & 0,35 & 0,73 & & 0,12 & 1,43 & 0,15 & & -0.04 & $-0,46$ & 0,65 & \\
\hline & Participation in decision making & $-0,11$ & $-1,10$ & 0,28 & & $-0,02$ & $-0,31$ & 0,76 & & 0.18 & 2,11 & $0,04^{*}$ & \\
\hline & SOC & $-0,27$ & $-3,23$ & $0,00^{* *}$ & & $-0,36$ & $-6,77$ & $0,00^{* *}$ & & -0.47 & $-7,38$ & $0,00^{* *}$ & \\
\hline
\end{tabular}

${ }^{* * *}$ Statistically significant $p \leq 0,01$

* Statistically significant $p \leq 0,05$

Note: For the young group, Model $1\left(F=13,43 ; R=0,49 ; \Delta R^{2}=0,22\right)$; Model $2\left(F=7,37 ; R=0,57 ; \Delta R^{2}=0,28\right)$; Model $3\left(F=8,21 ; R=0,61 ; \Delta R^{2}=0,33\right)$; For the middle group, Model $1\left(F=30,06 ; R=0,50 ; \Delta R^{2}=0,24\right)$; Model $2\left(F=15,14 ; R=0,56 ; \Delta R^{2}=0,29\right)$; Model $3\left(F=20,77 ; R=0,64 ; \Delta R^{2}=0,39\right)$. For the older group, Model $1(F=$ 26,$\left.51 ; R=0,57 ; \Delta R^{2}=0,31\right)$; Model $2\left(F=13,23 ; R=0,63 ; \Delta R^{2}=0,37\right)$; Model $3\left(F=21,77 ; R=0,74 ; \Delta R^{2}=0,53\right)$. 
Table 4 summarises the regression analyses with job demands, job resources, and SOC as predictors of exhaustion for young, middle-aged and older employees. Entry of job pressure, work load and emotional load at the first step of the regression analysis and entry of supervisor support, colleague support, role clarity, job information and participation in decision making entered in the second step of the regression analysis, resulted in both models producing a statistically significant model for young, middle-aged and older employees. The third step of the regression analysis produced a statistically significant model for young employees $\left(F_{(9,124)}=8,21 ; p=0,00 ; \Delta R^{2}=0,33\right)$ which explained approximately $37 \%$ of the variance; middle-aged employees $\left(F_{(9,270)}=20,77 ; p=0,00 ; \Delta R^{2}=0,39\right)$ which explained approximately $41 \%$ of the variance; and older employees $\left(F_{(9,158)}=21,77 ; p=0,00 ; \Delta R^{2}=\right.$ $0,53)$ which explained approximately $55 \%$ of the variance. According to the results, it seems that for young employees, job pressure $(\beta=0,21 ; t=2,10 ; p \leq 0,05)$, and emotional load $(\beta=$ $0,25 ; t=2,84 ; p \leq 0,05)$ predicted exhaustion; for middle-aged employees, job pressure $(\beta=$ $0,27 ; t=4,25 ; p \leq 0,05)$, emotional load $(\beta=0,18 ; t=3,29 ; p \leq 0,05)$ and supervisory support $(\beta=-0,17 ; t=-2,16 ; p \leq 0,05)$ predict exhaustion; and for older employees, mental load $(\beta=$ $0,30 ; t=4,38 ; p \leq 0,05)$, emotional load $(\beta=0,15 ; t=2,21 ; p \leq 0,05)$, supervisor support $(\beta=$ $-0,23 ; t=-2,55 ; p \leq 0,05)$ and lack of participation in decision making $(\beta=0,18 ; t=2,11 ; p \leq$ $0,05)$ seemed to predict exhaustion. Lower levels of SOC was a significant predictor of exhaustion for younger employees $(\beta=-0,27 ; t=-3,23 ; p \leq 0,05)$; middle-aged employees $(\beta$ $=-0,36 ; t=-6,77 ; p \leq 0,05)$; as well as older employees $(\beta=-0,47 ; t=-7,38 ; p \leq 0,05)$. 
Table 5

Hierarchical Multiple Regression Analysis with Cynicism as Dependent Variable

\begin{tabular}{|c|c|c|c|c|c|c|c|c|c|c|c|c|c|}
\hline \multirow[t]{2}{*}{ Model } & & $\underset{\beta}{\text { Standardised }}$ & $t$ & $p$ & $R^{2}$ & $\underset{\beta}{\text { Standardised }}$ & $t$ & $p$ & $R^{2}$ & $\underset{\beta}{\text { Standardised }}$ & $t$ & $p$ & $R^{2}$ \\
\hline & & \multicolumn{4}{|c|}{ Young } & \multicolumn{4}{|c|}{ Middle-aged } & \multicolumn{4}{|c|}{ Old } \\
\hline \multirow[t]{4}{*}{1} & (Constant) & & 2,59 & 0,01 & 0,11 & & 4,02 & 0,00 & 0,11 & & 0,48 & 0,63 & 0,14 \\
\hline & Job pressure & 0,06 & 0,55 & 0,58 & & 0,18 & 2,44 & $0,02^{*}$ & & $-0,07$ & $-0,74$ & 0,46 & \\
\hline & Mental load & $-0,20$ & $-1,69$ & 0,09 & & $-0,28$ & $-3,68$ & $0,00^{* *}$ & & 0,02 & 0,20 & 0,84 & \\
\hline & Emotional load & 0,37 & 3,92 & $0,00^{* *}$ & & 0,30 & 4,72 & $0,00^{* *}$ & & 0,40 & 4,77 & $0,00^{* *}$ & \\
\hline \multirow[t]{9}{*}{2} & (Constant) & & 5,59 & 0,00 & 0,33 & & 7,52 & 0,00 & 0,26 & & 5,01 & 0,00 & 0,30 \\
\hline & Job pressure & 0,02 & 0,15 & 0,88 & & 0,16 & 2,32 & $0,02^{*}$ & & $-0,14$ & $-1,62$ & 0,11 & \\
\hline & Mental load & $-0,13$ & $-1,17$ & 0,24 & & $-0,21$ & $-2,96$ & $0,00^{* *}$ & & 0,08 & 0,99 & 0,32 & \\
\hline & Emotional load & 0,31 & 3,59 & $0,00^{* *}$ & & 0,18 & 2,90 & $0,00^{* *}$ & & 0,24 & 3,02 & $0,00^{* * *}$ & \\
\hline & Supervisor support & $-0,00$ & $-0,01$ & 0,99 & & $-0,13$ & $-1,41$ & 0,16 & & $-0,02$ & $-0,15$ & 0,88 & \\
\hline & Colleague support & $-0,08$ & $-0,96$ & 0,34 & & $-0,07$ & $-1,19$ & 0,23 & & $-0,25$ & $-2,95$ & $0,00^{* *}$ & \\
\hline & Role Clarity & $-0,18$ & $-1,57$ & 0,12 & & $-0,13$ & $-1,40$ & 0,16 & & $-0,14$ & $-1,31$ & 0,19 & \\
\hline & Job information & 0,06 & 0,53 & 0,60 & & 0,10 & 0,98 & 0,33 & & $-0,10$ & $-0,88$ & 0,38 & \\
\hline & Participation in decision making & $-0,35$ & $-3,33$ & $0,00^{* *}$ & & $-0,22$ & $-2,57$ & $0,01^{* *}$ & & $-0,04$ & $-0,36$ & 0,72 & \\
\hline \multirow[t]{4}{*}{3} & (Constant) & & 7,02 & 0,00 & 0,40 & & 9,90 & 0,00 & 0,35 & & 7,10 & 0,00 & 0,41 \\
\hline & Job pressure & $-0,01$ & $-0,14$ & 0,89 & & 0,15 & 2,22 & $0,03^{*}$ & & $-0,14$ & $-1,81$ & 0,07 & \\
\hline & Mental load & $-0,12$ & $-1,15$ & 0,25 & & $-0,21$ & $-3,18$ & $0,00^{* *}$ & & 0,08 & 1,01 & 0,32 & \\
\hline & Emotional load & 0,22 & 2,53 & $0,01^{\text {** }}$ & & 0,11 & 1,91 & 0,06 & & 0,17 & 2,22 & $0,03^{*}$ & \\
\hline
\end{tabular}

${ }^{* * *}$ Statistically significant $p \leq 0,01$

* Statistically significant $p \leq 0,05$ 
Table 5 continued

Hierarchical Multiple Regression Analysis with Cynicism as Dependent Variable

\begin{tabular}{|c|c|c|c|c|c|c|c|c|c|c|c|c|}
\hline Model & $\underset{\beta}{\text { Standardised }}$ & $t$ & $p$ & $R^{2}$ & $\underset{\beta}{\text { Standardised }}$ & $t$ & $p$ & $R^{2}$ & $\underset{\beta}{\text { Standardised }}$ & $t$ & $p$ & $R^{2}$ \\
\hline & \multicolumn{4}{|c|}{ Young } & \multicolumn{4}{|c|}{ Middle-aged } & \multicolumn{4}{|c|}{ Old } \\
\hline Supervisor support & 0,02 & 0,24 & 0,81 & & $-0,10$ & $-1,17$ & 0,25 & & $-0,06$ & $-0,63$ & 0,53 & \\
\hline Colleague support & $-0,07$ & $-0,86$ & 0,39 & & $-0,07$ & $-1,11$ & 0,27 & & $-0,15$ & $-1,94$ & $0,05^{*}$ & \\
\hline Role Clarity & $-0,21$ & $-1,97$ & $0,05^{*}$ & & $-0,07$ & $-0,75$ & 0,45 & & $-0,07$ & $-0,76$ & 0,45 & \\
\hline Job information & 0,11 & 0,98 & 0,33 & & 0,09 & 0,98 & 0,33 & & $-0,11$ & $-1,02$ & 0,31 & \\
\hline Participation in decision making & $-0,28$ & $-2,72$ & $0,01^{* *}$ & & $-0,18$ & $-2,20$ & $0,03^{*}$ & & 0,06 & 0,59 & 0,55 & \\
\hline SOC & $-0,31$ & $-3,83$ & $0,00^{* *}$ & & $-0,34$ & $-6,11$ & $0,00^{* *}$ & & $-0,39$ & $-5,31$ & $0,00^{* *}$ & \\
\hline
\end{tabular}

*** Statistically significant $p \leq 0,01$

* Statistically significant $p \leq 0,05$

Note: For the young group, Model $1\left(F=5,50 ; R=0,34 ; \Delta R^{2}=0,09\right)$; Model $2\left(F=7,54 ; R=0,57 ; \Delta R^{2}=0,28\right)$; Model $3\left(F=9,06 ; R=0,63 ; \Delta R^{2}=0,35\right)$; For the middle group, Model $1\left(F=11,60 ; R=0,34 ; \Delta R^{2}=0,10\right)$; Model $2\left(F=11,72 ; R=0,51 ; \Delta R^{2}=0,24\right)$; Model $3\left(F=15,96 ; R=0,59 ; \Delta R^{2}=0,33\right)$. For the older group, Model $1(F=$ 9,$\left.01 ; R=0,38 ; \Delta R^{2}=0,13\right)$; Model $2\left(F=8,66 ; R=0,55 ; \Delta R^{2}=0,27\right)$; Model $3\left(F=12,14 ; R=0,64 ; \Delta R^{2}=0,38\right)$. 
Table 5 summarises the regression analyses with job demands, job resources, and SOC as predictors of cynicism for young, middle-aged and older employees. Entry of job pressure, work load and emotional load at the first step of the regression analysis and supervisor support, colleague support, role clarity, job information and participation in decision making entered in the second step of the regression analysis, both produced a statistically significant model for young employees, middle-aged employees and older employees. The third step of the regression analysis produced a statistically significant model for young employees $\left(F_{(9,124)}\right.$ $\left.=9,06 ; p=0,00 ; \Delta R^{2}=0,35\right)$ which explained approximately $40 \%$ of the variance; middleaged employees $\left(F_{(9,270)}=15,96 ; p=0,00 ; \Delta R^{2}=0,33\right)$ which explained approximately $35 \%$ of the variance; and older employees $\left(F_{(9,158)}=12,14 ; p=0,00 ; \Delta R^{2}=0,38\right)$ which explained approximately $41 \%$ of the variance. According to the results, it seems that for younger employees emotional load $(\beta=0,22 ; t=2,53 ; p \leq 0,05)$, role clarity $(\beta=-0,21 ; t=-1,97 ; p \leq$ $0,05)$ and a lack of inclusion in decision making $(\beta=-0,28 ; t=-2,72 ; p \leq 0,05)$ predicted cynicism, for middle-aged employees job pressure $(\beta=0,15 ; t=2,22 ; p \leq 0,05)$, mental load $(\beta=-0,21 ; t=-3,18 ; p \leq 0,05)$ and a lack of participation in decision making $(\beta=-0,18 ; t=-$ $2,20 ; p \leq 0,05)$ and for older employees only emotional load $(\beta=0,17 ; t=2,22 ; p \leq 0,05)$ and colleague support $(\beta=-0,15 ; t=-1,94 ; p \leq 0,05)$. Lower levels of SOC seem to be a significant predictor of cynicism for younger employees $(\beta=-0,31 ; t=-3,83 ; p \leq 0,05)$; middle-aged employees $(\beta=-0,34 ; t=-6,11 ; p \leq 0,05)$ and for older employees $(\beta=-0,39 ; t$ $=-5,31 ; p \leq 0,05)$. 
Table 6

Hierarchical Multiple Regression Analysis with Vigour as Dependent Variable

\begin{tabular}{|c|c|c|c|c|c|c|c|c|c|c|c|c|c|}
\hline Model & & $\begin{array}{c}\text { Standardised } \\
\beta\end{array}$ & $t$ & $p$ & $R^{2}$ & $\underset{\beta}{\text { Standardised }}$ & $t$ & $p$ & $R^{2}$ & $\underset{\beta}{\text { Standardised }}$ & $t$ & $p$ & $R^{2}$ \\
\hline & & \multicolumn{4}{|c|}{ Young } & \multicolumn{4}{|c|}{ Middle-aged } & \multicolumn{4}{|c|}{ Old } \\
\hline \multirow[t]{6}{*}{1} & (Constant) & & 3,07 & 0,00 & 0,30 & & 5,63 & 0,00 & 0,24 & & 4,46 & 0,00 & 0,20 \\
\hline & Supervisor support & 0,22 & 2,05 & $0,04^{*}$ & & 0,23 & 2,66 & $0,01^{* *}$ & & 0,07 & 0,56 & 0,57 & \\
\hline & Colleague support & 0,14 & 1,57 & 0,12 & & 0,19 & 3,06 & $0,00^{* *}$ & & 0,27 & 3,16 & $0,00^{* *}$ & \\
\hline & Role Clarity & 0,01 & 0,05 & 0,97 & & 0,04 & 0,38 & 0,70 & & $-0,15$ & $-1,37$ & 0,17 & \\
\hline & Job information & 0,01 & 0,08 & 0,94 & & $-0,08$ & $-0,78$ & 0,44 & & 0,24 & 2,03 & $0,04^{*}$ & \\
\hline & Participation in decision making & 0,29 & 2,74 & $0,01^{\text {** }}$ & & 0,20 & 2,29 & $0,02^{*}$ & & 0,08 & 0,77 & 0,44 & \\
\hline \multirow[t]{9}{*}{2} & (Constant) & & 3,87 & 0,00 & 0,38 & & 5,45 & 0,00 & 0,30 & & 4,35 & 0,00 & 0,23 \\
\hline & Supervisor support & 0,18 & 1,74 & 0,08 & & 0,16 & 1,80 & 0,07 & & 0,04 & 0,38 & 0,71 & \\
\hline & Colleague support & 0,12 & 1,44 & 0,15 & & 0,16 & 2,61 & $0,01^{\text {** }}$ & & 0,23 & 2,62 & $0,01^{\text {*** }}$ & \\
\hline & Role Clarity & $-0,01$ & $-0,05$ & 0,96 & & 0,03 & 0,31 & 0,76 & & $-0,15$ & $-1,35$ & 0,18 & \\
\hline & Job information & 0,06 & 0,52 & 0,60 & & $-0,07$ & $-0,69$ & 0,49 & & 0,28 & 2,31 & $0,02^{*}$ & \\
\hline & Participation in decision making & 0,26 & 2,51 & $0,01^{* *}$ & & 0,22 & 2,56 & $0,01^{* * *}$ & & 0,05 & 0,51 & 0,61 & \\
\hline & Job pressure & $-0,14$ & $-1,40$ & 0,16 & & $-0,12$ & $-1,81$ & 0,07 & & 0,08 & 0,88 & 0,38 & \\
\hline & Mental load & 0,19 & 1,88 & 0,06 & & 0,20 & 2,92 & $0,00^{* *}$ & & $-0,12$ & $-1,30$ & 0,19 & \\
\hline & Emotional load & $-0,29$ & $-3,50$ & $0,00^{* * *}$ & & $-0,22$ & $-3,63$ & $0,00^{* *}$ & & $-0,13$ & $-1,57$ & 0,12 & \\
\hline \multirow[t]{4}{*}{3} & (Constant) & & 1,51 & 0,13 & 0,42 & & 1,94 & 0,05 & 0,42 & & 1,90 & 0,06 & 0,38 \\
\hline & Supervisor support & 0,16 & 1,60 & 0,11 & & 0,12 & 1,56 & 0,12 & & 0,10 & 0,98 & 0,33 & \\
\hline & Colleague support & 0,11 & 1,36 & 0,18 & & 0,15 & 2,67 & $0,01^{* *}$ & & 0,12 & 1,46 & 0,15 & \\
\hline & Role Clarity & 0,02 & 0,21 & 0,83 & & $-0,05$ & $-0,58$ & 0,57 & & $-0,23$ & $-2,26$ & $0,03^{*}$ & \\
\hline
\end{tabular}

${ }^{* * *}$ Statistically significant $p \leq 0,01$

* Statistically significant $p \leq 0,05$ 
Table 6 continued

Hierarchical Multiple Regression Analysis with Vigour as Dependent Variable

\begin{tabular}{|c|c|c|c|c|c|c|c|c|c|c|c|c|}
\hline Model & $\begin{array}{c}\text { Standardised } \\
\beta\end{array}$ & $t$ & $p$ & $R^{2}$ & $\underset{\beta}{\text { Standardised }}$ & $t$ & $p$ & $R^{2}$ & $\underset{\beta}{\text { Standardised }}$ & $t$ & $p$ & $R^{2}$ \\
\hline & \multicolumn{4}{|c|}{ Young } & \multicolumn{4}{|c|}{ Middle-aged } & \multicolumn{4}{|c|}{ Old } \\
\hline Job information & 0,02 & 0,19 & 0,85 & & $-0,06$ & $-0,68$ & 0,50 & & 0,28 & 2,65 & $0,01^{* *}$ & \\
\hline Participation in decision making & 0,20 & 1,97 & $0,05^{*}$ & & 0,17 & 2,15 & $0,03^{*}$ & & $-0,06$ & $-0,60$ & 0,55 & \\
\hline Job pressure & $-0,12$ & $-1,21$ & 0,23 & & $-0,10$ & $-1,68$ & 0,09 & & 0,09 & 1,05 & 0,30 & \\
\hline Mental load & 0,19 & 1,88 & 0,06 & & 0,20 & 3,25 & $0,00^{* *}$ & & $-0,11$ & $-1,38$ & 0,17 & \\
\hline Emotional load & $-0,21$ & $-2,58$ & $0,01^{* *}$ & & $-0,14$ & $-2,50$ & $0,01^{* *}$ & & $-0,04$ & $-0,54$ & 0,59 & \\
\hline SOC & 0,25 & 3,10 & $0,00^{* *}$ & & 0,40 & 7,67 & $0,00^{* *}$ & & 0,47 & 6,30 & $0,00^{* *}$ & \\
\hline
\end{tabular}

*** Statistically significant $p \leq 0,01$

${ }^{*}$ Statistically significant $p \leq 0,05$

Note: For the young group, Model $1\left(F=10,86 ; R=0,55 ; \Delta R^{2}=0,27\right)$; Model $2\left(F=9,43 ; R=0,61 ; \Delta R^{2}=0,34\right)$; Model $3\left(F=10,02 ; R=0,65 ; \Delta R^{2}=0,38\right)$; For the middle group, Model $1\left(F=17,65 ; R=0,50 ; \Delta R^{2}=0,23\right)$; Model $2\left(F=14,20 ; R=0,54 ; \Delta R^{2}=0,28\right)$; Model $3\left(F=21,84 ; R=0,65 ; \Delta R^{2}=0,40\right)$. For the older group, Model $1(F=$ 8,$\left.15 ; R=0,45 ; \Delta R^{2}=0,18\right) ;$ Model $2\left(F=5,86 ; R=0,48 ; \Delta R^{2}=0,19\right) ; \operatorname{Model} 3\left(F=10,88 ; R=0,62 ; \Delta R^{2}=0,35\right)$. 
Table 6 summarises the regression analyses with job demands, job resources and SOC as being predictors of vigour for young, middle-aged and older employees. Entry of supervisor support, colleague support, role clarity, job information and participation in decision making in the first step of the regression analysis and job pressure, work load, and emotional load entered in the second step of the regression analysis, produced a statistically significant model for young, middle-aged and older employees. The final step in the regression analysis also produced a statistically significant model for young employees $\left(F_{(9,124)}=10,02 ; p=0,00\right.$; $\left.\Delta R^{2}=0,38\right)$ which explained approximately $42 \%$ of the variance; middle-aged employees $\left(F_{(9,270)}=21,84 ; p=0,00 ; \Delta R^{2}=0,40\right)$ which explained approximately $42 \%$ of the variance; and older employees $\left(F_{(9,158)}=10,88 ; p=0,00 ; \Delta R^{2}=0,35\right)$ which explained approximately $38 \%$ of the variance. According to the results, it seems that for young employees emotional load $(\beta=-0,21 ; t=-2,58 ; p \leq 0,05)$ and inclusion in the decision making process $(\beta=0,20 ; t$ $=1,97 ; p \leq 0,05)$ seemed to predict vigour; for middle-aged employees colleague support $(\beta=$ $0,15 ; t=2,67 ; p \leq 0,05)$, sufficient participation in decision making $(\beta=0,17 ; t=2,15 ; p \leq$ $0,05)$, mental load $(\beta=0,20 ; t=3,25 ; p \leq 0,05)$ and emotional load $(\beta=-0,14 ; t=-2,50 ; p \leq$ $0,05)$ seems to predict vigour and for older employees role clarity $(\beta=-0,23 ; t=-2,26 ; p \leq$ $0,05)$ and job information $(\beta=0,28 ; t=2,65 ; p \leq 0,05)$ seems to be sufficient predictors of vigour. Further, higher levels of SOC seems to be a significant predictor of vigour for younger employees $(\beta=0,25 ; t=3,10 ; p \leq 0,05)$; middle-aged employees $(\beta=0,40 ; t=7,67$; $p \leq 0,05)$; as well as older workers $(\beta=0,47 ; t=6,30 ; p \leq 0,05)$. 
Table 7

Hierarchical Multiple Regression Analysis with Dedication as Dependent Variable

\begin{tabular}{|c|c|c|c|c|c|c|c|c|c|c|c|c|c|}
\hline \multirow[t]{2}{*}{ Model } & & $\underset{\beta}{\text { Standardised }}$ & $t$ & $p$ & $R^{2}$ & $\underset{\beta}{\text { Standardised }}$ & $t$ & $p$ & $R^{2}$ & $\begin{array}{c}\text { Standardised } \\
\beta\end{array}$ & $t$ & $p$ & $R^{2}$ \\
\hline & & \multicolumn{4}{|c|}{ Young } & \multicolumn{4}{|c|}{ Middle-aged } & \multicolumn{4}{|c|}{ Old } \\
\hline \multirow[t]{6}{*}{1} & (Constant) & & 2,22 & 0,03 & 0,36 & & 4,69 & 0,00 & 0,22 & & 4,17 & 0,00 & 0,19 \\
\hline & Supervisor support & 0,12 & 1,18 & 0,24 & & 0,11 & 1,28 & 0,20 & & 0,07 & 0,58 & 0,56 & \\
\hline & Colleague support & 0,06 & 0,75 & 0,46 & & 0,11 & 1,75 & 0,08 & & 0,14 & 1,63 & 0,11 & \\
\hline & Role Clarity & 0,06 & 0,59 & 0,56 & & 0,07 & 0,75 & 0,45 & & 0,01 & 0,06 & 0,95 & \\
\hline & Job information & $-0,05$ & $-0,41$ & 0,68 & & 0,02 & 0,25 & 0,80 & & 0,24 & 1,99 & $0,05^{*}$ & \\
\hline & Participation in decision making & 0,48 & 4,78 & $0,00^{* *}$ & & 0,23 & 2,65 & $0,01^{* *}$ & & 0,08 & 0,72 & 0,47 & \\
\hline \multirow[t]{9}{*}{2} & (Constant) & & 1,32 & 0,19 & 0,43 & & 2,77 & 0,01 & 0,25 & & 1,79 & 0,08 & 0,24 \\
\hline & Supervisor support & 0,13 & 1,29 & 0,20 & & 0,07 & 0,82 & 0,41 & & 0,01 & 0,09 & 0,93 & \\
\hline & Colleague support & 0,08 & 1,00 & 0,32 & & 0,11 & 1,79 & 0,07 & & 0,18 & 2,09 & $0,04^{*}$ & \\
\hline & Role Clarity & 0,08 & 0,80 & 0,43 & & 0,04 & 0,39 & 0,70 & & 0,06 & 0,51 & 0,61 & \\
\hline & Job information & $-0,04$ & $-0,33$ & 0,74 & & 0,04 & 0,37 & 0,71 & & 0,22 & 1,87 & 0,06 & \\
\hline & Participation in decision making & 0,42 & 4,35 & $0,00^{* *}$ & & 0,25 & 2,84 & $0,01^{* *}$ & & 0,09 & 0,89 & 0,37 & \\
\hline & Job pressure & 0,19 & 1,96 & $0,05^{*}$ & & 0,04 & 0,61 & 0,55 & & 0,29 & 3,19 & $0,00^{* *}$ & \\
\hline & Mental load & 0,08 & 0,84 & 0,40 & & 0,17 & 2,41 & $0,02^{*}$ & & $-0,07$ & $-0,75$ & 0,45 & \\
\hline & Emotional load & $-0,26$ & $-3,34$ & $0,00^{* *}$ & & $-0,15$ & $-2,46$ & $0,02^{*}$ & & $-0,08$ & $-0,95$ & 0,34 & \\
\hline \multirow[t]{4}{*}{3} & (Constant) & & $-0,52$ & 0,61 & 0,47 & & $-0,22$ & 0,83 & 0,35 & & $-0,82$ & 0,41 & 0,41 \\
\hline & Supervisor support & 0,11 & 1,14 & 0,26 & & 0,04 & 0,53 & 0,60 & & 0,07 & 0,68 & 0,50 & \\
\hline & Colleague support & 0,07 & 0,91 & 0,37 & & 0,10 & 1,75 & 0,08 & & 0,07 & 0,84 & 0,40 & \\
\hline & Role Clarity & 0,11 & 1,06 & 0,29 & & $-0,03$ & $-0,35$ & 0,73 & & $-0,02$ & $-0,23$ & 0,82 & \\
\hline
\end{tabular}

${ }^{* * *}$ Statistically significant $p \leq 0,01$

${ }^{*}$ Statistically significant $p \leq 0,05$ 
Table 7 continued

Hierarchical Multiple Regression Analysis with Dedication as Dependent Variable

\begin{tabular}{|c|c|c|c|c|c|c|c|c|c|c|c|c|}
\hline Model & $\underset{\beta}{\text { Standardised }}$ & $t$ & $p$ & $R^{2}$ & $\underset{\beta}{\text { Standardised }}$ & $t$ & $p$ & $R^{2}$ & $\underset{\beta}{\text { Standardised }}$ & $t$ & $p$ & $R^{2}$ \\
\hline & \multicolumn{4}{|c|}{ Young } & \multicolumn{4}{|c|}{ Middle-aged } & \multicolumn{4}{|c|}{ Old } \\
\hline Job information & $-0,07$ & $-0,66$ & & & 0,04 & 0,46 & 0,64 & & 0,23 & 2,19 & $0,03^{*}$ & \\
\hline Participation in decision making & 0,37 & 3,85 & & & 0,20 & 2,48 & $0,01^{* *}$ & & $-0,02$ & $-0,23$ & 0,82 & \\
\hline Job pressure & 0,21 & 2,23 & & & 0,06 & 0,91 & 0,37 & & 0,29 & 3,66 & $0,00^{* * *}$ & \\
\hline Mental load & 0,08 & 0,81 & & & 0,17 & 2,61 & $0,01^{* *}$ & & $-0,06$ & $-0,77$ & 0,44 & \\
\hline Emotional load & $-0,20$ & $-2,47$ & & & $-0,08$ & $-1,40$ & 0,16 & & 0,01 & 0,19 & 0,85 & \\
\hline SOC & 0,22 & 2,86 & & & 0,35 & 6,42 & $0,00^{* *}$ & & 0,48 & 6,60 & $0,00^{* * *}$ & \\
\hline
\end{tabular}

${ }^{* * *}$ Statistically significant $p \leq 0,01$

${ }^{*}$ Statistically significant $p \leq 0,05$

Note: For the young group, Model $1\left(F=14,45 ; R=0,60 ; \Delta R^{2}=0,34\right)$; Model $2\left(F=11,80 ; R=0,66 ; \Delta R^{2}=0,40\right)$; Model $3\left(F=11,99 ; R=0,68 ; \Delta R^{2}=0,43\right)$; For the middle group, Model $1\left(F=14,99 ; R=0,46 ; \Delta R^{2}=0,20\right)$; Model $2\left(F=11,36 ; R=0,50 ; \Delta R^{2}=0,23\right)$; Model $3\left(F=16,17 ; R=0,59 ; \Delta R^{2}=0,33\right)$. For the older group, Model $1(F=$ 7,$\left.62 ; R=0,44 ; \Delta R^{2}=0,17\right) ;$ Model $2\left(F=6,36 ; R=0,49 ; \Delta R^{2}=0,20\right) ; \operatorname{Model} 3\left(F=12,00 ; R=0,64 ; \Delta R^{2}=0,37\right)$. 
Table 7 summarises the regression analyses with job demands, job resources, and SOC as predictors of dedication for young, middle-aged and older employees. Entry of supervisor support, colleague support, role clarity, job information and participation in decision making in the first step of the regression analysis and entry of job pressure, work load, and emotional load in the second step of the regression analysis, did produce a statistically significant model for young, middle-aged employees and older employees. The third step of the regression analysis also produced a statistically significant model for young employees $\left(F_{(9,124)}=11,99\right.$; $\left.p=0,00 ; \Delta R^{2}=0,43\right)$ which explained approximately $47 \%$ of the variance; middle-aged employees $\left(F_{(9,270)}=16,17 ; p=0,00 ; \Delta R^{2}=0,33\right)$, which explained approximately $35 \%$ of the variance; and older employees $\left(F_{(9,158)}=12,00 ; p=0,00 ; \Delta R^{2}=0,37\right)$ which explained approximately $41 \%$ of the variance. More specifically, for younger employees, participation in decision making $(\beta=0,37 ; t=3,85 ; p \leq 0,05)$, job pressure $(\beta=0,21 ; t=2,23 ; p \leq 0,05)$ and emotional load $(\beta=-0,20 ; t=-2,47 ; p \leq 0,05)$ seems to predict dedication, for middle aged employees participation in decision making $(\beta=0,20 ; t=2,61 ; p \leq 0,05)$ and mental load $(\beta=0,17 ; t=2,61 ; p \leq 0,05)$ and for older workers job information $(\beta=0,23 ; t=2,19 ; p$ $\leq 0,05)$ and job pressure $(\beta=0,29 ; t=2,19 ; p \leq 0,05)$. According to the results, it seems that a higher SOC seems to be a significant predictor of dedication for younger employees $(\beta=$ $0,22 ; t=2,86 ; p \leq 0,05)$; middle-aged employees $(\beta=0,35 ; t=6,42 ; p \leq 0,05)$; as well as older workers $(\beta=0,48 ; t=6,60 ; p \leq 0,05)$. Based on the above results no support was found for the hypotheses stated above and therefore Hypothesis $3 \mathrm{a}$ is partially accepted and Hypotheses $3 b$ and 4 are rejected. 
Table 8

Summary of Significant Predictors of Well-being across the three age groups

\begin{tabular}{|c|c|c|c|c|c|c|c|c|c|c|c|}
\hline \multicolumn{4}{|c|}{ YOUNG } & \multicolumn{4}{|c|}{ MIDDLE-AGED } & \multicolumn{4}{|c|}{ OLD } \\
\hline \multicolumn{12}{|c|}{ EXHAUSTION } \\
\hline & $\beta$ & $t$ & $p$ & & $\beta$ & $t$ & $p$ & & $\beta$ & $t$ & $p$ \\
\hline$R^{2}=37 \%$ & & & & $R^{2}=41 \%$ & & & & $R^{2}=55 \%$ & & & \\
\hline SOC & $-0,27$ & $-3,23$ & $0,00^{* *}$ & SOC & $-0,36$ & $-6,77$ & $0,00^{* *}$ & SOC & $-0,47$ & $-7,38$ & $0,00^{* *}$ \\
\hline Emotional load & 0,25 & 2,84 & $0,01^{* *}$ & Emotional load & 0,18 & 3,29 & $0,00^{* *}$ & Emotional load & 0,15 & 2,21 & $0,03^{*}$ \\
\hline \multirow[t]{6}{*}{ Job pressure } & 0,21 & 2,10 & $0,04^{*}$ & Job pressure & 0,27 & 4,25 & $0,00^{* *}$ & & - & - & - \\
\hline & - & - & - & Supervisor support & $-0,17$ & $-2,16$ & $0,03^{*}$ & Supervisor support & $-0,23$ & $-2,55$ & $0,01^{* *}$ \\
\hline & - & - & - & & - & - & - & Mental load & 0,30 & 4,38 & $0,00^{*}$ \\
\hline & - & - & - & & - & - & - & Participation in decision making & 0,18 & 2,11 & $0,04^{*}$ \\
\hline & & & & CYNICISM & & & & & & & \\
\hline & $\beta$ & $t$ & $p$ & & $\beta$ & $t$ & $p$ & & $\beta$ & $t$ & $p$ \\
\hline$R^{2}=40 \%$ & & & & $R^{2}=35 \%$ & & & & $R^{2}=41 \%$ & & & \\
\hline SOC & $-0,31$ & $-3,83$ & $0,00^{* *}$ & SOC & $-0,34$ & $-6,11$ & $0,00^{* *}$ & SOC & $-0,39$ & $-5,31$ & $0,00^{* *}$ \\
\hline Participation in decision making & $-0,28$ & $-2,72$ & $0,01^{* *}$ & Participation in decision making & $-0,18$ & $-2,20$ & $0,03^{*}$ & & - & - & - \\
\hline Emotional load & 0,22 & 2,53 & $0,01^{* *}$ & & - & - & - & Emotional load & 0,17 & 2,22 & $0,03^{*}$ \\
\hline \multirow[t]{4}{*}{ Role clarity } & $-0,21$ & $-1,97$ & $0,05^{*}$ & & - & - & - & & - & - & - \\
\hline & - & - & - & Mental load & $-0,21$ & $-3,18$ & $0,00^{* *}$ & & - & - & - \\
\hline & - & - & - & Job pressure & 0,15 & 2,22 & $0,03^{*}$ & & - & - & - \\
\hline & - & - & - & & - & - & - & Colleague support & $-0,15$ & $-1,94$ & $0,05^{*}$ \\
\hline
\end{tabular}

** Statistically significant $p \leq 0,01$

* Statistically significant $p \leq 0,05$ 
Table 8 continued

Summary of Significant Predictors of Well-being across the three age groups

\begin{tabular}{|c|c|c|c|c|c|c|c|c|c|c|c|}
\hline \multicolumn{4}{|c|}{ YOUNG } & \multicolumn{4}{|c|}{ MIDDLE-AGED } & \multicolumn{4}{|c|}{ OLD } \\
\hline \multicolumn{12}{|c|}{ VIGOUR } \\
\hline & $\beta$ & $t$ & $p$ & & $\beta$ & $t$ & $p$ & & $\beta$ & $t$ & $p$ \\
\hline$R^{2}=42 \%$ & & & & $R^{2}=42 \%$ & & & & $R^{2}=38 \%$ & & & \\
\hline SOC & 0,25 & 3,10 & $0,00^{* *}$ & SOC & 0,40 & 7,67 & $0,00^{* *}$ & SOC & 0,47 & 6,30 & $0,00^{* * *}$ \\
\hline Participation in decision making & 0,20 & 1,97 & $0,05^{*}$ & Participation in decision making & 0,17 & 2,15 & $0,03^{*}$ & & - & - & - \\
\hline \multirow[t]{7}{*}{ Emotional load } & $-0,21$ & $-2,58$ & $0,01^{* *}$ & Emotional load & $-0,14$ & $-2,50$ & $0,01^{* *}$ & & - & - & - \\
\hline & - & - & - & & - & - & - & Role clarity & $-0,23$ & $-2,26$ & $0,03^{*}$ \\
\hline & - & - & - & & - & - & - & Job information & 0,28 & 2,65 & $0,01^{* *}$ \\
\hline & - & - & - & Colleague support & 0,15 & 2,67 & $0,01^{* *}$ & & - & - & - \\
\hline & - & - & - & Mental load & 0,20 & 3,25 & $0,00^{* *}$ & & - & - & - \\
\hline & \multicolumn{7}{|c|}{ DEDICATION } & & & & \\
\hline & $\beta$ & $t$ & $p$ & & $\beta$ & $t$ & $p$ & & $\beta$ & $t$ & $p$ \\
\hline$R^{2}=47 \%$ & & & & $R^{2}=35 \%$ & & & & $R^{2}=41 \%$ & & & \\
\hline SOC & 0,22 & 2,86 & $0,01^{* *}$ & SOC & 0,35 & 6,42 & $0,00^{* *}$ & SOC & 0,48 & 6,60 & $0,00^{* *}$ \\
\hline Participation in decision making & 0,37 & 3,85 & $0,00^{* *}$ & Participation in decision making & 0,20 & 2,48 & $0,01^{* *}$ & & - & - & - \\
\hline Job pressure & 0,21 & 2,23 & $0,03^{*}$ & & - & - & - & Job pressure & 0,29 & 3,66 & $0,00^{* * *}$ \\
\hline \multirow[t]{3}{*}{ Emotional load } & $-0,20$ & $-2,47$ & $0,02^{*}$ & & - & - & - & & - & - & - \\
\hline & - & - & - & Mental load & 0,17 & 2,61 & $0,01^{* *}$ & & - & - & - \\
\hline & - & - & - & & - & - & - & Job information & 0,23 & 2,19 & $0,03^{*}$ \\
\hline
\end{tabular}

** Statistically significant $p \leq 0,01$

${ }^{*}$ Statistically significant $p \leq 0,05$ 
Table 8 constitutes a summary of all the significant findings across the three age groups. The most significant finding of the study was that SOC levels consistently predict all four wellbeing dimensions for all three age groups. The importance of this resource influencing burnout and work engagement seems to increase as the age of the employees increase. Further emotional load was the only job characteristic that seemed to be a significant predictor of exhaustion for all three age groups. For younger employees, an increase in emotional load seemed to predict exhaustion and cynicism, while a decrease seemed to predict vigour and dedication. An increase in emotional load only predicted exhaustion for middle-aged employees, while a decrease predicted vigour, whereas an increase in emotional load only predicted exhaustion and cynicism for older employees. An increase in job pressure seemed to predict exhaustion and cynicism for middle-aged employees whilst only predicting exhaustion for younger employees. An increase in job pressure, however, also seems to predict dedication for young and older employees. Insufficient supervisor support seemed to predict exhaustion in middle-aged and older employees and the need for supervisor support seemed to be higher for older employees than for middle-aged employees.

When older managers tend to experience high levels of mental load it leads to higher levels of exhaustion while for middle-aged employees a decrease in mental load seems to predict cynicism. Furthermore an increase of middle-aged employees' mental load seemed to predict both vigour and dedication. Exclusion in the decision making process seemed to predict lower exhaustion levels for older employees while younger and middle-aged junior managers seem to welcome the idea of being a part of the decision making process as this seems to lead to higher levels of vigour and dedication. Young employees also seemed to prefer clear guidelines for their role in the organisation otherwise they tend to experience higher levels of cynicism while older employees seem to prefer less role clarity as this seems to lead to higher vigour levels. Middle-aged and older employees seem to both value colleague support, as it seems to lead to higher levels of dedication and lower levels of cynicism respectively. Finally it seemed that older employees were the only group which valued job information as a sufficient job resource as it seemed to lead to higher levels of vigour and dedication. This model explained approximately $37 \%$ (young employees), $41 \%$ (middle-aged employees) and $55 \%$ (older employees) of the variance respectively. 


\section{DISCUSSION}

The aims of this study were to firstly to determine if age groups in the financial sector differ in their levels of burnout and work engagement and secondly to determine if a particular prediction model (including job demands, job resources and personal resources) is different for different age groups. In order to reach these two objectives, a sample of junior managers in the financial sector was divided into three age groups: young employees (18-30 years), middle-aged employees (31-50 years) and older employees (51-65 years).

The first objective was to establish whether there were any significant differences between the three age groups with regard to burnout and work engagement. With regards to burnout, significant differences were found for exhaustion, where younger and middle-aged employees experienced significantly higher levels of exhaustion compared to their older colleagues. This result led to the partial confirmation of Hypothesis 1 as there were significant differences found between young, middle-aged and older workers. However, no differences were found for cynicism. This finding is supported by Brewer and Shapard (2004) in that they also found that younger employees experienced higher levels of exhaustion than their older colleagues. These results also partially coincide with Jackson and Rothmann's (2005) findings on educators in South Africa, which found that exhaustion levels seems to be higher for younger employees than middle-aged or older employees. However, they also found significant differences on the cynicism dimension in educators which was not the case for this sample of the junior banking managers. A possible reason for these young managers experiencing higher levels of exhaustion can be the fact they are yet to develop coping skills as they are just entering the workforce and do not have the necessary experience to deal with the challenges posed by their new job (Brewer \& Shapard, 2004).

Hypothesis 2 was also partially confirmed. Although the results did not reveal significant differences between age groups for engagement, the results of the post-hoc analysis indicated that there were significant differences between younger and older employees regarding their dedication levels, with older employees experiencing higher levels of dedication than their younger counterparts. These results yielded similar results when compared with other findings, that is, older employees seemed to exhibit higher levels of engagement than the younger employees (Pitt-Catsouphes \& Matz-Costa, 2008; Schaufeli, Bakker \& Salanova, 
2006). Young junior managers may experience lower dedication levels than those of their older counterparts as they are just entering their organisation and may not have had sufficient time to create a meaningful relationship with the organisation yet. Peeters and Van Emmerik (2008) assert in their review article, that older employees seem to be more satisfied with their work, which can also be a reason why they tend to be more dedicated to their organisation than the young junior managers.

The second objective was to determine if the predictors (job demands, job resources) differed across the three age groups. The results indicated firstly that all the job demands which predict burnout and work engagement seemed to differ for the three age groups, except for emotional load. Emotional load was the only job demand which predicted exhaustion levels for all three age groups. The level of emotional load which led to exhaustion was much higher for younger than older employees. This can again be linked back to the young employees' lack of experience to enable them to effectively handle emotional stressors at work, having recently entered the work force (Laschinger et al., 2009). Middle-aged and older employees would be able to more easily draw on the coping skills that they have acquired and developed over the years. De Lange et al. (2010) concluded from literature that older workers may be able to control their emotions better and therefore these employees might be more likely to "use passive, intrapersonal emotion-focused forms of coping skills instead of active problem-focused behaviour" (p. 929). Hypothesis 3a is therefore partially confirmed as emotional load was similar across all three age groups. It was further found that the job demand which predicted exhaustion for young and middle-aged employees were job pressure, whereas it predicted dedication for older employees, and an increase in mental load, which seemed to predict vigour and a decrease in cynicism for middle-aged employees, while an increase of the same predicted exhaustion was evident in older employees.

It was interesting to find that some job demands (i.e., mental load and job pressure) led to positive well-being. This result is supported by Rothmann and Jordaan's (2006) results which also found that amongst South African higher institution educators job demands such as overload (including mental load) was positively correlated to the dedication dimension of engagement. Lepine, Podsakoff and Lepine (2005) explain this notion by highlighting two types of stressors, namely challenge and hindrance stressors. At times, certain job demands may tend to lead to negative outcomes ("hindrance stressors") while at other times employees may regard these demands as a challenge ("challenge stressors") in achieving their goals 
(Lepine et al., 2005). In this study it appeared that for young as well as older junior managers, an experience of high job pressure led to higher levels of dedication and middle-aged employees seemed to perceive that an increase in mental load was a significant predictor for their work engagement, while a decrease was a significant predictor of their cynicism levels. Lorente, Salanova, Martinez and Schaufeli (2008) support the result across their population of secondary school teachers' well-being, where they found that the teachers (average age of 40) also perceived mental load as a challenge, which ultimately seemed to yield higher levels of vigour over time. This is an important finding of the present study of junior managers as organisations in South Africa can recognise that certain job demands could aid as challenges for the employees and consequently could result in higher levels of work engagement although this might not be true for all occupations and sectors. However, it is important to note that although employees seem to thrive when experiencing higher levels of job demands it will only yield positive results when they have the sufficient job resources to meet those demands (Bakker, Van Veldhoven \& Xanthopoulou, 2010).

The findings secondly revealed that the job resources which predict burnout and work engagement seem to differ for all three age groups. Hypothesis $3 \mathrm{~b}$ is therefore rejected. Perceived organisational support (i.e., colleague support, role clarity, job information, and participation in decision-making) seemed to be sufficient predictors of engagement across all three age groups, a finding which is supported by Rothmann and Jordaan (2006), who also found that organisational support is positively related to engagement in their population sample of academic staff from tertiary institutions. Interestingly, participation in decision making seemed to be of much more importance in the prediction of work engagement for young and middle-aged employees, whilst it seemed to lead to exhaustion for older employees. Being included in the decision making process also seems to predict a resulting reduction in cynicism for young and middle aged employees. Markos and Sridevi (2010) emphasise that including young and middle-aged employees in the decision making process will make them feel a sense of importance and belonging and ultimately may positively influence their engagement levels. These young and middle-aged managers may thrive when they feel a sense of belonging in the organisation, knowing that they mean something in the organisation, while older employees might feel they are at the end of their time in office and thus might no longer wish to be part of the decision-making process. 
The results showed that job information was valued by only older employees and it seemed to ultimately lead to work engagement. Role clarity seemed to be negatively related to vigour in older employees and to cynicism in younger employees. For middle-aged employees, colleague support seemed to significantly predict vigour, while a lack thereof seemed to significantly predict cynicism in older employees and a lack of supervisor support seems to lead to high exhaustion levels in both middle-aged and older workers. James et al. (2011) contradict this finding however, as they found that supervisor support was a significant predictor for younger and older employees. Younger employees nevertheless did not seem to value colleague or supervisor support in the prediction of their well-being. This finding is also supported by Karatepe and Olugbade (2009) in that their research indicated that supervisor support did not have any effect on work engagement. This is an important finding as previous studies have found that ensuring that employees who perceive sufficient support from their colleagues and supervisors as important predictors get that support which can lead to higher job satisfaction (Cambré, Kippers, Van Veldhoven \& De Witte, 2012). Overlooking the importance of providing colleague and supervisor support to those who value it can lead to those employees experiencing burnout (Kalimo et al., 2003).

The third objective was to determine whether SOC is a significant predictor for young, middle-aged and older employees. The results indicated that SOC levels consistently predict all four well-being dimensions for all three age groups. The importance of this resource influencing burnout and engagement seems to increase as the age of the employee increases. As a result of this finding, Hypothesis 4 is rejected. Across all four dimensions of well-being it seemed that the older the employee, the more they seem to draw on their personal resources such as SOC, to reduce their burnout levels and enhance their work engagement levels. Consequently, it seems that when employees have high SOC it supports them in the selection of adequate strategies to deal with any work stressor they may encounter, which could result in an increase of their levels of well-being (Van der Colff \& Rothmann, 2009). It is therefore suggested that an increase in age appears to result in junior managers being equipped in dealing more effectively with their job demands as they gain valuable experience within their job. Being more experienced in a job can make the difference between effectively handling stressors and not coping, potentially leading in turn to burnout (Love, Goh, Hogg, Robson \& Irani, 2011)). As the results consistently illustrated, SOC which increases with age, is a strong predictor of burnout and work engagement, these results give even more reason to study this concept further in order to determine whether results are similar across a range of other 
occupations. The results however contradict literature, which theorised and found that SOC levels seem to not differ across age groups (Antonovsky, 1987; Feldt et al.,2003). Having a strong SOC (such as the older, junior managers showed) "enables the worker to evaluate potential stressors as benign or irrelevant and thus supports problem-solving in stressful situations, which prevents mental breakdown at work" (Kalimo, 2003, p.119).

In conclusion, the following main findings for the present study were produced. Young and middle-aged employees seemed to differ from older employees in their experience of exhaustion as they presented higher levels of exhaustion. The post-hoc analysis on work engagement revealed that older employees seemed to be more dedicated than their younger counterparts. However, there were no significant differences found across the three groups regarding cynicism and vigour. It was also found that different job demands and resources seemed to predict burnout and work engagement with the exception of emotional load which was a significant predictor for exhaustion across all three age groups. An important finding for South African literature, individuals and organisations, was that SOC across the three age groups was a significant predictor of burnout and work engagement. SOC levels seemed to increase with age, which could be a result of experience gained from having been in the workplace longer. The present study yielded important results that can be very beneficial for organisations to take into consideration when exploring well-being further in other occupations as well as for the junior managers in the banking industry.

\section{Limitations}

The main limitation of the study is that it made use of cross sectional design when collecting the data whereas a longitudinal study could have shown a causal relationship regarding age and its implications. The second limitation is that self report measures were used. The use of self report measures is often stated to lead to "common method variance problems", although consensus has not yet been reached on whether or not this is problematic (Podsakoff, MacKenzie, Lee \& Podsakoff, 2003; Spector 2006; Tremblay \& Messervey, 2011). A larger sample may have also yielded more significant results as the results would be more reliable when generalised. A final limitation is that this study only focused junior bank managers. Consequently, this study is not able to be generalised across different occupations or sectors. 


\section{Recommendations}

The present study yielded important findings as it shows organisations the importance of constantly monitoring their employees' well-being levels, as the results illustrate that wellbeing is differently perceived across age. Also having employees with high levels of wellbeing can lead to the success of the organisation. Similar to previous research findings (Antoniou et al., 2006; Brewer \& Shapard, 2004; Patrick \& Lavery, 2007; Randall, 2007), the results showed that young and middle-aged employees seem to experience higher levels of exhaustion, a point which should raise concern with organisations to explore this notion further as to why this might be the case and therefore the importance of focusing on the wellbeing of younger employees (Akkermans et al., 2009). This research highlighted certain job demands and resources that predict burnout and work engagement for the junior managers as it can assist organisations in the development of interventions for well-being based on the results of the important role that certain job demands and resources specifically play in this process. Although these results are specifically applicable to junior managers in the financial sector in South Africa, additionally it can be used to advocate other occupational organisations to explore this notion of age differences as every employment position has its own respective job demands and resources required to complete tasks. It is also worthwhile for organisations to explore the value of personal resources further as the results of the study consistently indicated that the older the employee, the higher their SOC levels.

As the results illustrated, personal resources, that is SOC, was a significant predictor for wellbeing across young, middle-aged and older junior managers with the importance of SOC seemingly increasing with age. Younger junior managers can take initiative by developing and learning relevant coping styles as these can help them with the everyday problems they might face as they do not always possess the relevant experience to draw on that older employees might have. It is now possible for these junior managers to see that there are differences in how other age groups perceive well-being, as well as what other groups value in terms of job demands and resources. Individuals should consequently start looking at age as a "new diversity issue" as this can assist them in effectively working together in the organisation (James et al., 2011). Employees from all ages can take this into account when interacting with each other; this might also enhance communication between the different age groups. 
Future researchers can duplicate this study over a longer period of time as a longitudinal study may yield other significant results as the change from one age group into another age group might practically show how certain experiences and perceptions of well-being may or may not have changed. Qualitative designs could be used in combination with the self report measures, which could control for the state of mind of the employee at the time of data gathering. A larger sample may also yield more significant results. It is recommended that further studies are conducted in this regard in South African organisations as there currently seem to be very limited studies on age in the South African context. Literature regarding age across different occupations and sectors are particularly needed for South African organisations as the present study focused on one occupational sector only. Lastly, as every occupation has its own set of job demands and job resources which can predict the well-being of employees, future research can also focus on job specific demands and resources. This study has highlighted the importance of job demands and resources in predicting employee well-being for junior managers; similarly, other occupations can benefit from knowing what job demands and resources and personal resources lead to their employees' well-being across the range of their different ages. 


\section{REFERENCES}

Ahola, K., Honkonen, T., Isometä, E., Kalimo, R., Nykyri, E., Aromaa, A., \& Lönnqvist, J. (2006). Burnout in the general population: Results from the Finnish Health 2000 study. Social Psychiatry Psychiatric Epidemiology, 41, 11-17.

Akkermans, J., Brenninkmeijer, V., Blonk, R. W. B., \& Koppes, L. L. J. (2009). Fresh and healthy? Well-being, health and performance of young employees with intermediate education. Career Development International, 14(7), 671-699.

Antoniou, A. S., Polychroni, F., \& Vlachakis, A. N. (2006). Gender and age differences in occupational stress and professional burnout between primary and high-school teachers in Greece. Journal of Managerial Psychology, 21(7), 682-690.

Antonovsky, A. (1979). Health, stress and coping: new perspectives on mental and physical well-being. San Francisco, CA: Jossey-Bass.

Antonovsky, A. (1987). Unraveling the mystery of health. San Francisco, CA: Jossey-Bass

Bakker, A. B., \& Demerouti, E. (2008). Towards a model of work engagement. Career Development International, 13(3), 209 - 223

Bakker, A. B., Demerouti, E., \& Euwema, M. C. (2005). Job resources buffer the impact of job demands on burnout. Journal of Occupational Health Psychology, 10(2), 170-180.

Bakker, A. B., Hakanen, J. J., Demerouti, E. \& Xanthopoulou, D. (2007). Job resources boost work engagement, particularly when job demands are high. Journal of Educational Psychology, 99(2), 274-284.

Bakker, A. B., Demerouti, E., \& Verbeke, W. (2004).Using the Job demands-resources model to predict burnout and performance.Human Resource Management, 43(1), 83-104.

Bakker, A. B., Demerouti, E., \& Schaufeli, W. B. (2003). Dual processes at work in a call centre: An application of the job demands-resources model. European Journal of Work and Organizational Psychology, 12(4), 393-417.

Bakker, A. B., Van Emmerik, H., \& Euwema, M. C. (2006). Crossover of burnout and engagement in work teams. Work and Occupations, 33(4), 464-489.

Bakker, A. B., Van Veldhoven, M., \& Xanthopoulou, D. (2010). Beyond the demand-control model: Thriving on high job demands and resources. Journal of Personnel Psychology, 9(1), 3-16.

Baptiste, N. R. (2008). Tightening the link between employee wellbeing at work and performance: A new dimension for HRM. Management Decision, 46(2), 384-309. 
Brewer, E. W., \& Shapard, L. (2004). Employee Burnout: A meta-analysis of the relationship between age or years of experience. Human Resource Development Review, 3(2), 102-123.

Cambré, B., Kippers, E., Van Veldhoven, M., \& De Witte, H. (2012). Jobs and organisations: Explaining group level differences in job satisfaction in the banking sector. Personnel Review, 41(2), 200-215.

Cooper, C. L. (2005). The future of work: Careers, stress and well-being. Career Development International, 10(5), 369-399.

Cordes, C. L., \& Dougherty, T. W. (1993). A review and an integration of research on job burnout. The Academy of Management Review, 18(4). 621-656.

De Lange, A. H., Taris, T. W., Jansen, P., Kompier, M. A. J., Houtman, I. L. D., \& Bongers, P. M. (2010). On the relationships among work characteristics and learning-related behaviour: Does age matter? Journal of Organizational Behavior, 31, 925-950.

Duchscher, J. E. B. (2009). Transition shock: The initial stage of role adaptation for newly graduated Registered Nurses. Journal of Advanced Nursing, 65, 1103-1113.

Feldt, T., Leskinen, E., Kinnunen, U., \& Ruoppila, I. (2003). The stability of sense of coherence: Comparing two age groups in a 5-year follow-up study. Personality and Individual Differences, 35, 1151-1165.

Garner, B. R., Knight, K., \& Simpson, D. D. (2007). Burnout among corrections-based drug treatment staff: Impact of individual and organizational factors. International Journal of Offender Therapy and Comparative Criminology, 51(5), 510-522.

Ghorpade, J., Lackritz, J., \& Singh, G. (2007). Burnout and personality: Evidence from academia. Journal of Career Assessment, 15(2), 240-256.

Hakanen, J. J., Bakker, A. B., \& Schaufeli, W. B. (2006). Burnout and work engagement among teachers. Journal of School Psychology, 43, 495-513.

Hakanen, J. J., Schaufeli, W. B., \& Ahola, K. (2008). The Job Demands-Resources model: A three year cross-lagged study of burnout, depression, commitment, and work engagement. Work \& Stress, 22(3), 224-241.

Hansson, A., Hilleras, P., \& Forsell, Y. (2005). Well-being in an adult Swedish population. Social Indicators Research, 74, 313-325.

Jackson, L. T. B., \& Rothmann, S. (2005). An adapted model of burnout for educators in South Africa. South African Journal of Education, 25(2), 100-108.

James, J. B., McKechnie, S., \& Swanberg, J. (2011). Predicting employee engagement in an age-diverse retail workforce. Journal of Organizational Behavior, 32, 173-196. 
Kalimo, R., Pahkin, K., Mutanen, P., \& Toppinen-Tanner, S. (2003). Staying well or burning out at work: Work characteristics and personal resources as long-term predictors. Work \& Stress, 17(2), 109-122.

Karatepe, O. M., \& Olugbade, O. A. (2009). The effects of job and personal resources on hotel employees' work engagement. International Journal of Hospitality Management, 28, 504-512.

Khattak, J. K., Khan, M. A., Haq, A. U., Arif, M., \& Minhas, A. A. (2011). Occupational stress and burnout in Pakistan's banking sector. African Journal of Business Management, $5(3), 810-817$.

Korunka, C., Kubicek, B., Schaufeli, W. B., \& Hoonakker, P. (2009). Work engagement and burnout: Testing the robustness of the Job Demands-Resources model. The Journal of Positive Psychology, 4(3), 243-255.

Laschinger, H. K. S., Wilk, P., Cho, J., \& Greco, P. (2009). Empowerment, engagement and perceived effectiveness in nursing work environments: Does experience matter? Journal of Nursing Management, 17, 636-646.

Leiter, M. P. (1993). Burnout as a developmental process: Consideration of models. In W. B. Schaufeli, C. Maslach, \& T. Marek (Eds.), Professional burnout (pp. 237-250). Washington, DC: Taylor \& Francis.

Lepine, J. A., Podsakoff, N. P., \& Lepine, M. A. (2005). A meta-analytic test of the challenge stressor-hindrance stressor framework: An explanation for inconsistent relationships among stressors and performance. The Academy of Management Journal, 48(5), 764-775.

Lorente, L., Salanova, M., Martínez, I., \& Schaufeli, W. (2008). Extension of the job Demands-Resources model in the prediction of burnout and engagement among teachers over time. Psicothema, 20(3), 354-360.

Love, P. E. D., Goh, Y. M., Hogg, K., Robson, S., \& Irani, Z. (2011). Burnout and sense of coherence among residential real estate brokers. Safety Science, 49, 1297-1308.

Markos, S., \& Sridevi, M. S. (2010). Employee engagement: The key to improving performance. International Journal of Business and Management, 5(12), 89-96.

Maslach, C., \& Leiter, M. P. (2008). Early predictors of job burnout and engagement. Journal of Applied Psychology, 93(3), 498-512.

Maslach, C., \& Schaufeli, W. B., \& Leiter, M. P. (2001). Job burnout. Annual Review of Psychology, 52, 397-422.

Nunnally, J. C., \& Bernstein, I. H. (1994). Psychometric theory (3rd Ed.). New York: McGraw-Hill. 
Patrick, K., \& Lavery, J. F. (2007). Burnout in Nursing. Australian Journal of Advanced Nursing, 24(3), 43-48.

Peeters, M. C. W., \& Van Emmerik, H. (2008). An introduction to the work and well-being of older workers: From the managing threats to creating opportunities. Journal of Managerial Psychology, 23(4), 353-363.

Pitt-Catsouphes, M., \& Matz-Costa, C. (2008). The multi-generational workforce: Workplace flexibility and engagement. Community, Work \& Family, 11(2), 215-229.

Podsakoff, P. M., MacKenzie, S. B., Lee, J. Y., \& Podsakoff, N. P. (2003). Common method biases in behavioural research: A critical review of the literature and recommended remedies. Journal of Applied Psychology, 88(5), 879-903.

Randall, K. J. (2007). Examining the relationship between burnout and age among Anglican clergy in England and Wales. Mental Health, Religion \& Culture, 10(1), 39-46.

Rothmann, S., \& Joubert, J. H. M. (2007). Job demands, job resources, burnout and work engagement of managers at a platinum mine in the North West Province. South African Journal of Business Management, 38(3), 49-61.

Rothmann, S., \& Jordaan, G. M. E. (2006). Job demands, job resources and work engagement of academic staff in South African higher education institutions. South African Journal of Industrial Psychology, 32(4), 87-96.

Rothmann, J. C., \& Rothmann, S. (2006). The South African Employee Health and Wellness Survey: User manual. Potchefstroom: Afriforte (Pty) Ltd.

Saks, A. M. (2006). Antecedents and consequences of employee engagement. Journal of Managerial Psychology, 21(7), 600-619.

Salkind, N. J. (2009). Exploring research. (7th ed.). Upper Saddle River, NJ: Pearson Education, Inc.

Schaufeli, W. B., \& Bakker, A. B. (2004). Job demands, job resources, and their relationship with burnout and engagement: A multi-sample study. Journal of Organizational Behavior, $25,293-315$.

Schaufeli, W. B., Bakker, A. B., \& Salanova, M. (2006). The measurement of work engagement with a short questionnaire. Educational and Psychological Measurement, 66(4), 701-716.

Schaufeli, W. B., Salanova, M., González-Romá, V., \& Bakker, A. B. (2002). The measurement of engagement and burnout: A two sample confirmatory factor analytical approach. Journal of Happiness Studies, 3, 71-92. 
Spector, P.E. (2006). Method variance in organizational research: Truth or urban legend? Organizational Research Methods, 9(2), 221-232.

SPSS Inc. (2008). SPSS 16.0 for Windows. Chicago, IL: SPSS Inc.

Struwig, F. W., \& Stead, G. B. (2001). Planning, designing and reporting research. Cape Town: Maskew Miller Longman (Pty) Ltd.

Ten Brummelhuis, L. L., Ter Hoeven, C. L., Bakker, A. B., \& Peper, B. (2011). Breaking through the loss cycle of burnout: The role of motivation. Journal of Occupational and Organizational Psychology 84, 268-287.

Tremblay, M. A., \& Messervey, D. (2011). The job demands-resources model: Further evidence for the buffering effect of personal resources. South African Journal of Industrial Psychology, 37(2), 1-10.

Van der Colff, J. J., \& Rothmann, S. (2009). Occupational stress, sense of coherence, coping, burnout and work engagement of registered nurses in South Africa. South African Journal of Industrial Psychology, 35(1), 1-10.

Van der Walt, S., \& Du Plessis, T. (2010). Age diversity and the aging librarian in academic libraries in South Africa. South African Journal of Libraries \& Information Science, 76(1), $1-10$.

Visser, W., \& Rothmann, S. (2008). Exploring antecedents and consequences of burnout in a call centre. South African Journal of Industrial Psychology, 34(2), 79-87.

Westman, M., \& Bakker, A. B. (2008). Crossover of burnout among health care professionals. In J. R. B. Halbesleben (Eds.), Handbook of Stress and Burnout in Health Care, pp. 1-16. Nova Science Publishers.

Xanthopoulou, D., Bakker, A. B., Demerouti, E. \& Schaufeli, W. B. (2007). The role of personal resources in the job demands-resources model. International Journal of Stress Management, 14(2), 121-141. 


\section{CHAPTER 3}

\section{CONCLUSIONS, LIMITATIONS AND RECOMMENDATIONS}

This chapter concludes the mini-dissertation by summarising the results in terms of the general and the specific objectives. Limitations to the research will be discussed and lastly recommendations are made for future research, individuals as well as organisations.

\subsection{CONCLUSIONS}

The aim of this study was to determine whether age groups (young, middle-aged and older employees) differed in their levels of burnout and work engagement and if certain predictors (job demands, job resources, sense of coherence) of burnout and work engagement differed across the three age groups of junior managers in the financial sector. As little research was found on the topic in a South African context, this study contributes to the fact that in South Africa, age does seem to play a role in the burnout and work engagement levels of junior managers and therefore it is important for organisations to take into account age differences in their organisations as well as the differences in the predictors of well-being across age. In the previous chapter, the results were discussed and accordingly the following conclusions can be drawn.

The first objective was to determine the relationship between age, burnout and work engagement, job characteristics (job demands and job resources), and sense of coherence as a personal resource, according to literature. Where burnout and work engagement were concerned, literature accentuated the importance of studying these two concepts in order to aid in the assurance of a successful organisation. Having burnt out employees in the organisation can lead to many negative results for both the organisation as well as the individual. The organisation could suffer from employees experiencing job dissatisfaction, and exhibiting low levels of organisational commitment, absenteeism, and intention to leave the organisation (Maslach \& Leiter, 2008). On an individual level, employees could suffer from chronic fatigue that hinders optimal performance and their behaviour might also change negatively towards the company as well as the clients as a result of experiencing high levels of burnout (Bakker, Van Emmerik \& Euwema, 2006). Consequently, the importance of 
having an engaged workforce can be stressed. The literature regarding work engagement even state that having an engaged work force is the key to the success and competitive advantage of any organisation and that performance will increase with engaged employees (Gruman \& Saks, 2011; McBain, 2006). Employees also seem to demonstrate higher quality relationships with the organisation as well as higher organisational commitment when they are engaged (Saks, 2006; Hakanen, Bakker \& Schaufeli, 2006).

Various authors suggest that certain factors such as age can play a role in the burnout and work engagement levels of employees (Garner, Knight \& Simpson, 2007; James, McKechnie $\&$ Swanberg, 2011). Numerous studies were found linking burnout and its two core concepts (exhaustion and cynicism) to age and all the studies yielded the same results that younger employees demonstrated higher levels of burnout than their older colleagues (Antoniou, Polychroni \& Vlachakis, 2006; Brewer \& Shapard, 2004; Patrick \& Lavery, 2007; Randall, 2007). Even in South Africa this seemed to be the case (see Jackson \& Rothmann, 2005). Research also revealed that burnout seemed to prevail more among younger employees regardless of their occupation as evident in various studies across different occupations (e.g. the Anglican Clergy, nursing and education professions) (Jackson \& Rothmann, 2005; Patrick \& Lavery, 2007; Randall, 2007). Reasons for this result included a lack of coping skills to deal with everyday problems as a result of a lack of experience, a reality shock from having just entered the workforce for the first time, and transition shock (Ahola et al., 2006; Duchscher, 2009; Ghorpade, Lackritz \& Singh, 2007; Patrick \& Lavery, 2007). Therefore, it can be concluded that younger workers appear to experience higher levels of burnout than their middle aged or older colleagues. Work engagement on the other hand seemed to yield results to the contrary as studies found that older employees seemed to experience higher levels of engagement than their younger counterparts did (James et al., 2011; Laschinger, Wilk, Cho \& Greco, 2009; Pitt-Catsouphes \& Matz-Costa, 2008; Shaufeli, Bakker \& Salanova, 2006). Based on the findings in the relevant literature, it can therefore be stated that older employees seem to experience higher levels of engagement than their younger or middle aged counterparts.

The Job Demands-Resources (JD-R) model is used in research to explain the process of burnout and work engagement and how it is predicted (Demerouti, Bakker, De Jonge, Janssen \& Schaufeli, 2001; Bakker, Demerouti \& Verbeke, 2004; Schaufeli, Bakker \& Van Rhenen, 2009). The two processes explained by the JD-R model are the energetic (high job demands 
leads to ill health via burnout) and motivational (sufficient job resources to deal with job demands lead to organisational commitment via engagement) processes (Schaufeli \& Bakker, 2004). Many studies have concluded that the JD-R model predicts that when an employee has sufficient job resources, it assists employees to sufficiently and effectively deal with their job demands (Bakker, Demerouti \& Schaufeli, 2003; Bakker et al., 2004; Hakanen et al., 2006). Research on age and the JD-R model concluded that age seemed to be invariant across the model and therefore there does not seem to be different job demands and resources explaining the different levels of burnout and work engagement (James et al., 2011; Korunka, Kubicek, Schaufeli \& Hoonakker, 2009). James et al. (2011), however, did find that career development and promotion did differ across age as the job demands and job resources which predicted burnout and work engagement. In conclusion, there does not appear to be any difference across the age groups with regards to what predicts burnout and work engagement.

Apart from job demands and job resources, another type of resource (i.e. personal resource) also seems to play a role in the model. According to Xanthopoulou, Bakker, Demerouti and Schaufeli (2007), sense of coherence (SOC) is a personal resource that plays an important role in the explanation of the JD-R model. Certain researchers label SOC as being the most important personal resource (Kalimo, Pahkin, Mutanen \& Toppinen-Tanner, 2003). Limited research found that SOC was linked with age. The father of SOC, Antonovsky (1987), however, theorised that SOC would stabilise by the age of 30 and therefore stop developing unless there major change occurred during a person's lifetime. However, Feldt, Leskinen, Kinnunen, and Ruoppila (2003), in their study over a span of five years, found that there seemed to be no difference among younger and older employees with regards to their age and SOC levels and concluded that age therefore seemed to also be invariant across SOC levels. SOC therefore also seems not to differ across age groups.

The second objective was to determine whether there were any significant differences between young, middle-aged, and older employees with regards to their experience of burnout and work engagement. The results indicate that young and middle-aged employees seemed to experience higher levels of exhaustion than their older colleagues. Cynicism did not differ across the age groups. This result led to the partial confirmation of Hypothesis 1 and confirmed the conclusions drawn by researchers who had carried out studies on age and burnout differences (Patrick \& Lavery, 2007; Jackson \& Rothmann, 2005). Specifically, the current findings confirm those of Brewer and Shapard (2004) as they also found a significant 
relationship between age and exhaustion. Reasons for this finding can be the nature of a bank managers job (constantly having to work hard as a result of a high workload) and therefore they can become easily exhausted as they are still new in the workplace and are still learning the culture of the organisation and developing coping skills (Ghorpade et al., 2007; Khattak, Khan, Haq, Arif \& Minhas, 2011). There were no differences found across the age groups and work engagement, however, in the post-hoc analysis, significant differences were found between young and older employees regarding their dedication levels. This result coincided with previous research findings (Pitt-Catsouphes \& Matz-Costa, 2008; Schaufeli et al., 2006). This finding led to the partial confirmation of Hypothesis 2 as there did not seem to be differences in age with regards to the vigour dimension.

The third objective was to determine if job demands and resources differ across the age groups. Hierarchical multiple regression analysis revealed that the predictors of well-being across the three age groups differed with the exception of emotional load, which was a significant predictor of exhaustion across all three age groups. These results lead to the partial confirmation of Hypothesis 3a and the rejection of Hypothesis 3b. However, this finding contradicted other findings that concluded that there did not seem to be a difference in the job demand and resources, which predicted burnout and work engagement (see James et al., 2011; Korunka et al., 2009). Interestingly, it also appears that certain job demands lead to higher work engagement levels across the three age groups. A result which is explained by Lepine, Podsakoff and Lepine (2005) in their study in which it was found that employees can at times thrive on job demands and thus view those job demands as challenges. However, sufficient job resources must be available for them to meet the job demands (Bakker, Van Veldhoven \& Xanthopoulou, 2010).

The regression analysis further indicates that the SOC levels of young, middle-aged and older junior managers differed significantly across the three age groups. The results indicate that the older the employee the greater their reliance on their SOC levels to reduce their burnout levels and enhance their work engagement levels. This finding leads to the rejection of Hypothesis 4 as there were differences found in the levels of SOC across the three age groups. The findings of the present study however oppose other theories and findings in literature (Antonovsky, 1987; Feldt et al., 2003). Maintaining SOC levels high will assist employees in effectively recognising and dealing with work stressors optimally (Kalimo et al., 2003). 


\subsection{LIMITATIONS}

The main limitation of the study is that it made use of a cross sectional design when collecting the data. In the case of a cross sectional design, no causal relationships can be established whereas with longitudinal studies, a causal relationship can be examined further, for example, age and its implications.

The second limitation is the fact that self report measures were used. The use of self report measures is often considered to lead to "common method variance problems" (Tremblay \& Messervey, 2011). However, consensus has not yet been reached in literature on whether or not it should be considered a problem (e.g. Podsakoff, MacKenzie, Lee \& Podsakoff, 2003; Spector 2006). A larger sample may also have yielded more significant results as the results would be more reliable when generalised.

A final limitation is that this study focused on only one population, namely, junior bank managers. Consequently, these results might not be applicable to other sectors or occupations as the observed tendencies found in this study could differ across other occupations.

\subsection{RECOMMENDATIONS}

Despite the limitations mentioned above, this research does yield further insight into the important role that age plays in the determination of the experience of burnout and work engagement in organisations.

\subsubsection{Recommendations for the organisation}

The present study yielded important findings for organisations. It demonstrates the importance of constantly monitoring the levels of well-being of their employees as the present study clearly indicated that well-being is differently perceived across the age groups. Similar to previous research findings (Antoniou et al., 2006; Brewer \& Shapard, 2004; Patrick \& Lavery, 2007; Randall, 2007), the results also indicated that young and middleaged employees appear to experience higher levels of exhaustion which should raise concern with organisations to explore this notion further as to why this might be the case. Therefore, the importance for organisations to focus on younger employees within the organisation is 
again accentuated as the results clearly reveal that it is the younger employees who experience higher levels of exhaustion (Akkermans, Brenninkmeijer, Blonk \& Koppes, 2009). This research highlighted certain job demands and resources that predict burnout and work engagement among the junior managers. This information can be used in the development of interventions to promote well-being in the financial sector as the important role that certain job demands and resources specifically play are reported. Although these results are applicable to only junior managers in the financial sector in South Africa, it could encourage other organisations to also explore this notion of age differences across other occupations as every job has its own relevant job demands and resources needed to complete a task. It is also noteworthy for organisations to explore the importance of personal resources further as the results consistently indicated that the older the employee the higher their SOC levels.

\subsubsection{Recommendations for the individual}

As the results illustrated, personal resources (i.e., SOC) was a significant predictor for wellbeing across young, middle-aged, and older junior managers. However, the importance of SOC seems to increase with age. Younger junior managers can take the initiative by developing or learning relevant coping styles to help them with everyday problems that they might face, as they might not always possess the relevant experience that older employees might do. This study offers junior managers in the banking sector further knowledge with regards to the differences in how other age groups perceive well-being as well as what they value in terms of job demands and resources. Therefore individuals should begin to consider age as a "new diversity issue" as this can assist them in effectively working together in the organisation (James, McKechnie \& Swanberg, 2011). Employees from all ages can take this into account when interacting with each other as this might enhance communication between the different age groups.

\subsubsection{Recommendations for future research}

Future researchers can duplicate this study over a longer period. A longitudinal study may yield other significant results as the progression from one age group to another might practically reveal how certain experiences and perceptions of well-being may or may not have changed. Moreover, qualitative designs could be used in combination with the self report measures in order to yield concrete results as the researcher might also be able to control for the state of mind of the employee at the time of data gathering. A larger sample 
might also yield more significant results. In particular, in order to contribute to the body of knowledge in South African literature, it is recommended that further studies be conducted in South African organisations, because currently, there appears to be very limited studies on age in the South African context. In particular, further studies regarding age across different occupations and sectors are needed for South African organisations as the present study focused only on junior managers in the banking industry. Lastly, as every occupation has its own set of job demands and job resources, which can predict the well-being of employees, future research can also focus on job specific demands and resources. As this study highlighted the importance of job demands and resources predicting employee well-being for junior managers, other occupations could also benefit from knowing what job demands and resources lead to the well-being of their employees across the different age groups. 


\section{REFERENCES}

Ahola, K., Honkonen, T., Isometä, E., Kalimo, R., Nykyri, E., Aromaa, A., \& Lönnqvist, J. (2006). Burnout in the general population: Results from the Finnish Health 2000 Study. Social Psychiatry Psychiatric Epidemiology, 41, 11-17.

Akkermans, J., Brenninkmeijer, V., Blonk, R. W. B., \& Koppes, L. L. J. (2009). Fresh and healthy? Well-being, health and performance of young employees with intermediate education. Career Development International, 14(7), 671-699.

Antoniou, A. S., Polychroni, F., \& Vlachakis, A. N. (2006). Gender and age differences in occupational stress and professional burnout between primary and high-school teachers in Greece. Journal of Managerial Psychology, 21(7), 682-690.

Antonovsky, A. (1987). Unraveling the mystery of health. San Fransisco, CA: Jossey-Bass.

Bakker, A. B., Demerouti, E., \& Schaufeli, W. B. (2003). Dual processes at work in a call centre: An application of the job demands-resources model. European Journal of Work and Organizational Psychology, 12(4), 393-417.

Bakker, A. B., Demerouti, E., \& Verbeke, W. (2004).Using the Job Demands-Resources model to predict burnout and performance. Human Resource Management, 43(1), 83-104.

Bakker, A. B., Van Emmerik, H., \& Euwema, M. C. (2006). Crossover of burnout and engagement in work teams. Work and Occupations, 33(4), 464-489.

Bakker, A. B., Van Veldhoven, M., \& Xanthopoulou, D. (2010). Beyond the demand-control model: Thriving on high job demands and resources. Journal of Personnel Psychology, 9(1), 3-16.

Brewer, E. W., \& Shapard, L. (2004). Employee burnout: A meta-analysis of the relationship between age or years of experience. Human Resource Development Review, 3(2), 102-123.

Demerouti, E., Bakker, A. B., De Jonge, J., Janssen, P. P. M., \& Schaufeli, W. B. (2001). Burnout and engagement at work as a function of demands and control. Scandinavian Journal Work Environment Health, 27(4), 279-286.

Duchscher, J. E. B. (2009). Transition shock: The initial stage of role adaptation for newly graduated registered nurses. Journal of Advanced Nursing, 65, 1103-1113.

Feldt, T., Leskinen, E., Kinnunen, U., \& Ruoppila, I. (2003). The stability of sense of coherence: Comparing two age groups in a 5-year follow-up study. Personality and Individual Differences, 35, 1151-1165. 
Garner, B. R., Knight, K., \& Simpson, D. D. (2007). Burnout among corrections-based drug treatment staff: Impact of individual and organizational factors. International Journal of Offender Therapy and Comparative Criminology, 51(5), 510-522.

Ghorpade, J., Lackritz, J., \& Singh, G. (2007). Burnout and personality: Evidence from academia. Journal of Career Assessment, 15(2), 240-256.

Gruman, J. A., \& Saks, A. M. (2011). Performance management and employee engagement. Human Resource Management Review, 21, 123-136.

Hakanen, J. J., Bakker, A. B., \& Schaufeli, W. B. (2006). Burnout and work engagement among teachers. Journal of School Psychology, 43, 495-513.

Jackson, L. T. B., \& Rothmann, S. (2005). An adapted model of burnout for educators in South Africa. South African Journal of Education, 25(2), 100-108.

James, J. B., McKechnie, S., \& Swanberg, J. (2011). Predicting employee engagement in an age-diverse retail workforce. Journal of Organizational Behavior, 32, 173-196.

Kalimo, R., Pahkin, K., Mutanen, P., \& Toppinen-Tanner, S. (2003). Staying well or burning out at work: Work characteristics and personal resources as long-term predictors. Work \& Stress, 17(2), 109-122.

Khattak, J. K., Khan, M. A., Haq, A. U., Arif, M., \& Minhas, A. A. (2011). Occupational stress and burnout in Pakistan's banking sector. African Journal of Business Management, 5(3), 810-817.

Korunka, C., Kubicek, B., Schaufeli, W. B., \& Hoonakker, P. (2009). Work engagement and burnout: Testing the robustness of the Job Demands-Resources model. The Journal of Positive Psychology, 4(3), 243-255.

Laschinger, H. K. S., Wilk, P., Cho, J., \& Greco, P. (2009). Empowerment, engagement and perceived effectiveness in nursing work environments: Does experience matter? Journal of Nursing Management, 17, 636-646.

Lepine, J. A., Podsakoff, N. P., \& Lepine, M. A. (2005). A meta-analytic test of the challenge stressor-hindrance stressor framework: An explanation for inconsistent relationships among stressors and performance. The Academy of Management Journal, 48(5), 764-775.

Maslach, C., \& Leiter, M. P. (2008). Early predictors of job burnout and engagement. Journal of Applied Psychology, 93(3), 498-512.

McBain, R. (2006). Employee engagement - the emergence of a new construct? Henley Manager Update, 17(4), 21-32.

Patrick, K., \& Lavery, J. F. (2007). Burnout in nursing. Australian Journal of Advanced Nursing, 24(3), 43-48. 
Pitt-Catsouphes, M., \& Matz-Costa, C. (2008). The multi-generational workforce: Workplace flexibility and engagement. Community, Work \& Family, 11(2), 215-229.

Podsakoff, P. M., MacKenzie, S. B., Lee, J. Y., \& Podsakoff, N. P. (2003). Common method biases in behavioural research: A critical review of the literature and recommended remedies. Journal of Applied Psychology, 88(5), 879-903.

Randall, K. J. (2007). Examining the relationship between burnout and age among Anglican clergy in England and Wales. Mental Health, Religion \& Culture, 10(1), 39-46.

Saks, A. M. (2006). Antecedents and consequences of employee engagement. Journal of Managerial Psychology, 21(7), 600-619.

Schaufeli, W. B., \& Bakker, A. B. (2004). Job demands, job resources, and their relationship with burnout and engagement: A multi-sample study. Journal of Organizational Behavior, $25,293-315$.

Schaufeli, W. B., Bakker, A. B., \& Salanova, M. (2006). The measurement of work engagement with a short questionnaire. Educational and Psychological Measurement, 66(4), 701-716.

Schaufeli, W. B., Bakker, A. B., \& Van Rhenen, W. (2009). How changes in job demands and resources predict burnout, work engagement, and sickness absenteeism. Journal of Organizational Behavior, 30, 893-917.

Spector, P.E. (2006). Method variance in organizational research: Truth or urban legend? Organizational Research Methods, 9(2), 221-232.

Tremblay, M. A., \& Messervey, D. (2011). The Job Demands-Resources model: Further evidence for the buffering effect of personal resources. South African Journal of Industrial Psychology, 37(2), 1-10.

Xanthopoulou, D., Bakker, A. B., Demerouti, E. \& Schaufeli, W. B. (2007). The role of personal resources in the job demands-resources model. International Journal of Stress Management, 14(2), 121-141. 